\title{
International tail risk and world fear
}

\author{
Article
}

Accepted Version

Creative Commons: Attribution-Noncommercial-No Derivative Works 4.0

Hollstein, F., Nguyen, D. B. B., Prokopczuk, M. and Wese Simen, C. (2019) International tail risk and world fear. Journal of International Money and Finance, 93. pp. 244-259. ISSN 0261-5606 doi: https://doi.org/10.1016/j.jimonfin.2019.01.004 Available at https://centaur.reading.ac.uk/81649/

It is advisable to refer to the publisher's version if you intend to cite from the work. See Guidance on citing.

To link to this article DOI: http://dx.doi.org/10.1016/j.jimonfin.2019.01.004

Publisher: Elsevier

All outputs in CentAUR are protected by Intellectual Property Rights law, including copyright law. Copyright and IPR is retained by the creators or other copyright holders. Terms and conditions for use of this material are defined in the End User Agreement.

\section{www.reading.ac.uk/centaur}

\section{CentAUR}

Central Archive at the University of Reading

Reading's research outputs online 


\title{
International Tail Risk and World Fear*
}

\author{
Fabian Hollstein $^{\dagger} \quad$ Duc Binh Benno Nguyen ${ }^{\dagger} \quad$ Marcel Prokopczuk $^{\dagger, \ddagger}$
}

Chardin Wese Simen ${ }^{\ddagger}$

January 7, 2019

\begin{abstract}
We examine the pricing of tail risk in international stock markets. Studying all MSCI Developed and Emerging Markets countries, we find that the tail risk of these countries is highly integrated. We find that both local and our newly computed global tail risk strongly predict global equity index excess returns. These results hold both in-sample and out-of-sample. Sorting countries into portfolios by their tail risk generates sizable excess returns across various holding periods. Finally, we find that global tail risk is linked to international economic activity.
\end{abstract}

JEL classification: G01, G11, G12, G17

Keywords: Jump Risk; Tail Risk; International Stock Market Returns; Return Predictability; International Asset Pricing; Factor Models

\footnotetext{
${ }^{*}$ We thank Kees Koedijk (the editor), an anonymous referee, Yufeng Han (EFA discussant), Michael Stutzer (MFA discussant), as well as participants at the meeting of the Eastern Finance Association (2017) and Midwest Finance Association (2017) and the research seminar in Leibniz University Hannover (2016) for valuable comments. We are especially grateful to Christoph Würsig for his help in collecting the data from Datastream. Contact: hollstein@fmt.uni-hannover.de (F. Hollstein), nguyen@fmt.uni-hannover.de (D.B.B Nguyen), prokopczuk@fmt.uni-hannover.de (M. Prokopczuk), and c.wese-simen@icmacentre.ac.uk (C. Wese Simen).

${ }^{\dagger}$ School of Economics and Management, Leibniz University Hannover, Koenigsworther Platz 1, 30167 Hannover, Germany.

${ }^{\ddagger}$ ICMA Centre, Henley Business School, University of Reading, Reading, RG6 6BA, U.K.
} 


\section{Introduction}

"Not every business cycle has a financial crisis.

Frequently they do."

- Kenneth Arrow

To study tail risk of asset returns has been the focus of recent studies, especially since past years have been marked by times of financial distress like the burst of the dot-com bubble, the Lehman default, the great recession followed by the European debt crisis and the Chinese stock market crash. In this paper, we contribute to this literature by studying tail risk in international equity markets. We examine the tail risk in a large international cross-section of all MSCI Developed and Emerging Markets countries.

We begin by analyzing the tail risk of each country separately and analyze tail risk comovements across countries, finding very rich dynamics across the tail risks of different countries. We find that the tail risk of each country both Granger-causes and is Grangercaused by that of several other countries. Motivated by this finding, we construct a global version of tail risk, which we call World Fear $(W F)$. World Fear is the market capitalization weighted average of the individual countries' tail risks. We then investigate the asset pricing implications of both tail risk and World Fear for international stock returns.

Our key findings can be summarized as follows. First, there is a positive and significant relationship between both local tail risk and World Fear and future aggregate market returns around the globe. Both local tail risk and World Fear significantly predict future aggregate market excess returns in-sample. We validate these results out-of-sample, finding high and positive out-of-sample $R^{2} \mathrm{~s}$ for all forecasting horizons, both for local tail risk and for World Fear.

Second, sorting the international equity indices into portfolios according to their local 
tail risk, we document a statistically significant spread return. For instance, the strategy that simultaneously buys equity indices in the portfolio with the high tail risk measure and sells indices included in the portfolio with the lowest tail measure generates an average annualized portfolio excess return of $6.36 \%$. The abnormal returns relative to the global Capital Asset Pricing Model (CAPM), Fama \& French (1993) 3-factor, and Carhart (1997) 4-factor models are of similar magnitude and also statistically significant. These findings extend to longer holding periods of up to 60 months.

Finally, we also present a potential explanation for the predictive power of tail risk. To achieve this goal, we explore the link between World Fear and the real economy. Our empirical results establish that an increase in World Fear is followed by higher unemployment in current and subsequent months for the majority of countries, followed by a slow recovery.

The estimation of tail risk can be generally separated into two strands of literature. The first is based on option implied measures. Using deep-out-of-the-money and short maturity options of the S\&P 500 index, Bollerslev et al. (2015) decompose the variance risk premium into a premium for diffusive risk and a premium for large movements referred to as jump risk. Cremers et al. (2015) use at-the-money S\&P 500 straddles to capture jump and volatility risk. More precisely, they relate jump and volatility risk to the Black-Scholes Greeks and create mimicking portfolios by ensuring that they are marketneutral, vega-neutral (vega-positive) and gamma-positive (gamma-neutral) for the jump (volatility) factor. The second stream directly relies on underlying return data. Bollerslev \& Todorov (2011) use high-frequency S\&P 500 index returns in order to quantify the tail risk of the S\&P 500 index. Kelly \& Jiang (2014) use the cross-section of stock returns in the U.S. to estimate the tail risk of the equity market. In the present paper, we employ 
the method of Kelly \& Jiang (2014) since the data requirements of other methods make a broad international study impossible.

While the dataset for options is limited for international countries, papers using tail risk estimation based on returns data mainly focus on the U.S., or on few large developed markets and a short sample period, as for example Andersen et al. (2018). We contribute to the literature by providing international evidence of tail risk based on returns data, using a large international dataset. ${ }^{1}$ Furthermore, we add to this stream of the literature by doing a cross-sectional analysis of international equity indices.

Our work also adds to the growing literature that analyzes the predictability of returns in an international context. For instance, Ang \& Bekaert (2007) study the predictive power of traditional predictors such as dividend yields and short rates in international countries. Bollerslev et al. (2014) introduce the global variance risk premium and show that it outperforms the local variance risk premium in predicting aggregate local market returns. Relative to these studies, we introduce a new predictor, which we denote World Fear, and contribute to the literature on international return predictability of both the aggregate market and the cross-section of countries. The impact of local tail risk and World Fear is both economically and statistically significant.

The rest of the paper is organized as follows. Section II describes our dataset and methodology. Section III discusses the results related to local and global tail risk and presents a possible economic mechanism. Section IV presents further analyses and Section V concludes.

\footnotetext{
${ }^{1}$ When we started this project, we could not find any study that focused on tail risk in international markets. After completing the first version of our paper, we have become aware of Wang (2016), who also examines international markets.
} 


\section{Data and Methodology}

\section{A Data}

Our primary dataset contains stock returns of all MSCI Developed and Emerging Markets countries. In total, our dataset comprises of the cross-sections of 48 different countries. Table 1 provides information on the countries, the average size of the respective cross-sections as well as summary statistics. Equity price and market capitalization data are obtained from Datastream, except for the U.S. data, which are from the Center for Research in Security Prices (CRSP). We include the universe of stocks from the major exchanges for each country, which are defined as the exchanges in which the majority of stocks are traded. ${ }^{2}$

The data span the period from January 1990 to December 2017, including a total of 7,082 trading days. As can be seen in Table 1, most companies are from the U.S. with an average of 4,919 stocks over the whole sample period, followed by Japan with an average of 2,412. Our sample also includes countries with rather small cross-sections such as Indonesia or Ireland, where the average number of stocks is 25. CRSP total returns (including dividends) are obtained directly from CRSP for the U.S. while local returns are calculated using total return indices for the remaining countries from Datastream. We conduct our analyses in U.S. dollar returns, converting the returns into U.S. dollar returns using the corresponding exchange rates from Datastream.

Following Lesmond (2005) and Lee (2011), we include all listed and delisted companies provided in the Datastream database, excluding Depository Receipts (DRs), Real

\footnotetext{
${ }^{2}$ Most countries have a single major exchange while there are two for Canada (Toronto and TSX), China (Shenzen and Shanghai), Germany (Frankfurt and Xetra), India (BSE Ltd. and National India), Japan (Osaka and Tokyo), South Korea (Korea and KOSDAQ), the United Arab Emirates (Abu Dhabi and Dubai Financial Market), and three for the U.S. (AMEX, NYSE, and NASDAQ).
} 
Estate Investment Trusts (REITs) and preferred stocks. In doing so, we apply the filters described in Appendix B, Tables B.1 and B.2, of Griffin et al. (2010). We include only major securities and primary quotes. For the U.S. market, we only include stocks with CRSP share codes 10 or 11. As in Hou et al. (2011) and Lee (2011), we exclude anomalous observations. More specifically, if the current or past return, $r_{t}$ or $r_{t-1}$, are higher than $100 \%$ and $\left(1+r_{t}\right)\left(1+r_{t-1}\right)-1<20 \%$ both $r_{t}$ and $r_{t-1}$ are set missing. Furthermore, following Griffin et al. (2010), we set any daily return greater than 200\% missing. ${ }^{3}$ Moreover, we require a minimum number of return observations per trading day. If more than $90 \%$ of the stocks have zero returns (in local currency) on a day, the day is declared as non-trading day and is dropped from the analysis (see, e.g., Amihud, 2002; Lesmond, 2005; Lee, 2011). We handle delistings following Ince \& Porter (2006) by setting all observations from the end of the sample period to the first non-zero domestic return missing. Lastly, we follow Hou \& Loh (2016) and discard stocks with a price lower than $\$ 1$. By taking this step, we aim to remove small and likely illiquid stocks from our sample.

Table 1 summarizes descriptive statistics for the daily returns of the cross-section of the individual countries. We report means, standard deviations, selected quantiles, as well as the skewness and kurtosis. All figures are in U.S. dollar currency. The equally weighted average cross-sectional mean return is between 0.02 and 0.06 percentage points for most of the countries, which corresponds to annualized mean returns between $5.0 \%$ and $15.1 \%$. For few countries, the mean is outside the aforementioned interval. One should note, though, that we report returns in U.S. dollar currency. Thus, the figures

\footnotetext{
${ }^{3}$ The cutoff levels of employed in existing studies are somewhat arbitrary. As robustness check, we therefore also estimate the tail risk parameter using raw data without any cutoffs. The correlations of the parameters based on raw and cleaned data are very close to 1 and the return predictability regressions deliver qualitatively and quantitatively similar results.
} 
we report reflect equally weighted average daily stock returns as well as exchange rate changes of the local currencies relative to the U.S. dollar.

\section{B Estimation of Tail Risk}

This section briefly describes the estimation procedure of the tail risk measure introduced by Kelly \& Jiang (2014), from now on referred to as JKTR. The tail risk is measured by the tail parameter of the tail distribution. The distribution of returns is assumed to obey a potentially time-varying power law and the tail parameter is estimated from the cross-section of stock returns. The tail probability distribution of an asset's return is given by:

$$
P\left(r_{i, t+1}^{*}<R \mid r_{i, t+1}^{*}<u_{t} ; \mathbb{F}_{t}\right)=\left(\frac{R}{u_{t}}\right)^{-a_{i} / \lambda_{t}}
$$

where $r_{i, t+1}^{*}$ is the return of asset $i$ on day $t+1, \mathbb{F}_{t}$ is the information set at time $t$ and $u_{t}$ is the tail threshold, where $R<u_{t}<0 .{ }^{4} a_{i} / \lambda_{t}$ is the tail exponent which determines the shape of the tail, where $a_{i}$ is a constant which determines the level of tail risk of a certain asset $i$ and $\lambda_{t}$, which we use as a measure of tail risk $\left(J K T R_{t}=\lambda_{t}\right)$, determines the common dynamics of the tail risk across assets. The $J K T R_{t}$ is estimated by the power law estimator of Hill (1975) using the cross-section of daily return observations for all stocks at time $t$, thus:

$$
J K T R_{t}=\frac{1}{K_{t}} \sum_{i=1}^{K_{t}} \log \left(r_{i, t}^{*}\right)-\log \left(u_{t}\right),
$$

\footnotetext{
${ }^{4}$ We rely on simple returns for our estimation, i.e., $r_{i, t}^{*}=\left(P_{i, t} / P_{i, t-1}\right)-1$, where $P_{i, t}$ is the total return price index of asset $i$ on day $t$. We denote the returns with a superscript $\left(^{*}\right)$ since we later work with excess returns, denoted as $r_{i, t}$.
} 
where $K_{t}$ is the total number of daily returns falling below the threshold $u_{t}$ for period t. Facing the trade-off between a sufficiently low threshold and an appropriate number of observations below it, the threshold is fixed to the $5 \%$ quantile of the cross-sectional return distribution using a month of daily return data (Kelly \& Jiang, 2014). The JKTR can be interpreted as a rate of decay in the left tail since a higher $\lambda_{t}$ results in a fatter left tail.

\section{International Tail Risk}

\section{A Estimation Results}

To get a feel for the characteristics of international tail risk, Table 2 reports summary statistics about the JKTR for each country separately. It is instructive to compare the average tail risk of the different countries. The higher the tail risk in a country, the more severe are the potential extreme tail events. Thus, investors investing in such a country face potentially severe losses in case of a tail event. The average tail risk is particularly large in Peru, the United Arab Emirates, Indonesia, Colombia, and Hungary (in descending order). ${ }^{5}$ In Taiwan, South Korea, Egypt, Italy, and Japan the tail risk is on average very low (in ascending order). Thus, these economies may be considered particularly "safe" in terms of their tail events. We find that the tail risk of the countries is typically persistent, indicated by high $A R(1)$-coefficients often exceeding 0.50 .

\footnotetext{
${ }^{5}$ In Section III.E, we examine whether investors investing in countries with high tail risk are compensated for this by higher returns.
} 


\section{B Granger Causality}

After examining each country individually, we now turn to lead-lag relationships of international tail risk. In order to quantify the interactions between the tail risks of different countries, we estimate vector autoregressive (VAR) models and perform a series of Granger causality tests (Granger, 1969). ${ }^{6}$ We use the following model:

$$
\left(\begin{array}{c}
J K T R_{t}^{i} \\
J K T R_{t}^{j}
\end{array}\right)=\left(\begin{array}{c}
\alpha_{1} \\
\alpha_{2}
\end{array}\right)+\sum_{p=1}^{P}\left(\begin{array}{cc}
\beta_{1, p} & \gamma_{1, p} \\
\beta_{2, p} & \gamma_{2, p}
\end{array}\right)\left(\begin{array}{c}
J K T R_{t-p}^{i} \\
J K T R_{t-p}^{j}
\end{array}\right)+\left(\begin{array}{c}
\epsilon_{i, t} \\
\epsilon_{j, t}
\end{array}\right)
$$

The null hypothesis that the tail risk JKTR of country $i$ does not Granger-cause the tail risk of country $j$ is rejected if the coefficients of the lagged terms of country $i$ in the equation of country $j$ are not jointly equal to zero. We test the joint significance of the coefficients using an F-test. The optimal lag order $P$ is chosen according to the Bayesian Information Criterion (BIC).

We summarize the results in Table 3. We detect very rich dynamics across the tail risks of all countries. The JKTR of each country significantly Granger-causes that of several other countries. Similarly, for each country, the JKTR is significantly Grangercaused by that of several others. Our results reflect the leading role of the U.S. in the world economy: the U.S. JKTR Granger-causes that of 42 other countries. It is worth noting that also the tail risk of Sweden, Singapore, and South Korea Granger-causes the tail risk of more than 36 other countries. The overall implication of these findings is that there is high interdependence of tail risk in the MSCI Developed and Emerging Markets countries with no completely clear-cut direction of causality.

\footnotetext{
${ }^{6}$ To ascertain that the series are stationary, we perform the Phillips-Perron test and the Augmented Dickey-Fuller test for each JKTR time series. We test the null hypothesis that the time series has a unit-root against the alternative of stationarity. The null can be rejected for all countries and each of the two tests.
} 


\section{World Fear}

Several studies investigate the integration of international financial markets and provide both empirical and theoretical evidence for an increase, especially for developed countries (King \& Levine, 1993; Levine, 1997; Rajan \& Zingales, 1998; Sarazervos, 1998; Beck et al., 2000; Edison et al., 2002; Levine et al., 2000; De Guevara et al., 2007). In addition, the transmission of shocks across borders often referred to as volatility spillover and contagion (Lin et al., 1994; Hamao et al., 1990; Allen \& Gale, 2000; Karolyi, 2003) is documented by various studies for the financial crisis 2007-2009 and the European debt crisis (Bekaert et al., 2014; Dungey \& Gajurel, 2015).

Given the high level of integration of developed and emerging markets and the presence of volatility spillover effects in addition to the lead-lag correlation we find, the question arises whether the tail risk of one country is relevant for market and stock returns or whether global tail risk is more important.

We thus aggregate the tail risk of individual countries to a World Fear Index as a proxy for global tail risk. We estimate World Fear $\left(W F_{t}\right)$ as the market capitalization weighted average of the individual tail risk estimates of each country:

$$
W F_{t}=\omega_{t}^{j} J K T R_{t}^{j}
$$

where $\omega_{t}^{j}$ is the time- $t$ share of the country's market capitalization in the total "world" market capitalization, which aggregates that of all countries in our sample. $J K T R_{t}^{j}$ is the tail risk of country $j .^{7}$

\footnotetext{
${ }^{7}$ Because the markets are heterogeneous and, consequently, the quality of the information about the tail risk is heterogeneous, it is sensible to weight the JKTR by the corresponding market capitalization when aggregating them to World Fear. We also considered World Fear defined as the equally weighted average of the individual tail risk estimates, which leads to qualitatively similar but somewhat weaker results.
} 
Figure 1 displays the time series of World Fear. Similar to the finding of Kelly \& Jiang (2014) for the U.S., we find that World Fear has no distinct peaks during recessions, but rather during expansions. Kelly \& Jiang (2014) argue that volatility is predictable over short horizons and that the JKTR is a volatility-adjusted measure. Thus, the high volatility in the crisis is mostly expected and absorbed in the continuous variation while the tail risk, or jump variation, does not exhibit a peak. Figure 2 illustrates this feature of the JKTR. The JKTR for the U.S. for example is very similar during both relatively calm $(09 / 2003)$ and turbulent $(09 / 2008)$ times: the obtained estimates are $J K T R_{2003}=$ $J K T R_{2008}=0.38$. But the relatively low estimate during the financial crisis is due to the time-varying threshold and the resulting volatility adjustment. The tail distribution is plotted for the two identical JKTR estimates but different thresholds. By utilizing a lower threshold the tail becomes drastically fatter, as it is the case during the financial crisis. The JKTR is hence a volatility-adjusted measure.

We present the descriptive statistics for World Fear in Table 2. World Fear has an average value of 0.37 . Not surprisingly, the tail risks of the U.S. and the U.K. exhibit the strongest correlations with World Fear, exceeding 70\%. However, also the tail risks of the Netherlands, Switzerland, Finland, and Australia are highly related to World Fear. On the other hand, the tail risks of Qatar, Thailand, Malaysia, and Saudi Arabia are only marginally correlated with World Fear. Thus, the tail risk of these rather small countries (in terms of their stock cross-sections) appears to matter least for the tail risk of the entire world. ${ }^{8}$

\footnotetext{
${ }^{8}$ We provide further evidence of a common component in the tail risk of individual countries by regressing the JKTR on our World Fear index. Table 4 shows that World Fear has strong explanatory power for the individual JKTR across all countries. The slope coefficient is positive and statistically significant for almost all countries and the adj. $R^{2}$ is typically sizable. Our findings are in line with the high positive contemporaneous correlations.
} 


\section{Time-Series Return Predictability}

The recent literature finds for the U.S. that high (low) tail risk is associated with relatively high (low) future excess market returns (see, e.g., Kelly \& Jiang, 2014; Bollerslev et al., 2014; Bollerslev et al., 2015). We test whether this finding holds for international data. We use the following regression model:

$$
r_{j, t+h}=a_{j, h}+b_{j, h} T R_{t}+\epsilon_{j, t+h}
$$

where $r_{j, t+h}$ is the continuously compounded market excess return in country $j$ over the horizon $h$ and $T R_{t}$ is either the local tail risk of country $j, J T K R_{j, t}$ or World Fear, $W F_{t}$. Monthly returns are in excess of the 1-month U.S. Treasury bill yield. We estimate Equation (5) for forecasting horizons between 1 and 60 months using panel regressions. To account for autocorrelation in the residuals imposed by the use of overlapping return data, as recommended by Petersen (2009), we cluster the standard errors both by country and by time period (Cameron et al., 2011). We focus our discussion on the estimated slope coefficients, their statistical significance and the forecast accuracy of the regressions as measured by the adjusted $R^{2}$.

Table 5 reports the results for the JKTR. We find that the local tail risk is a highly significant predictor of future aggregate market excess returns.

In Table 6, we repeat the analysis using World Fear as a predictor. Similarly to JKTR, we find that World Fear is a statistically significant predictor of future returns at all horizons. For all forecast horizons (except at the 60 -month horizon), the adjusted $R^{2}$ when using World Fear as a predictor is substantially higher than when using the local JKTR. Thereby, the predictive power is substantial already at the 9-month horizon and 
it exceeds $2 \%$ until the 36 -month horizon.

Having investigated the in-sample predictability, we now turn to an out-of-sample exercise. As argued by Welch \& Goyal (2008), it is not sufficient to only investigate in-sample tests since most of the predictors are unable to consistently forecast the equity premium out-of-sample. Most of their examined models underperform the recursive mean model out-of-sample. Similar to them, we use the historical mean as a benchmark for our models, which is given as:

$$
\bar{r}_{j, t+h}=\frac{1}{N-l+1} \sum_{i=t-N+1}^{t-l+1} r_{j, i}
$$

using only return observations realized until $t$. $N$ is the window length and $l$ denotes the return window, i.e., 1 for 1-month returns. Following Campbell \& Thompson (2008), we evaluate our models using the out-of-sample $R^{2}$ which measures the differences in mean squared prediction errors (MSPE) for the predictive model and the historical mean model, and is given by:

$$
R_{O O S, j}^{2}=1-\frac{\sum_{t=N}^{T}\left(r_{j, t+1}-\hat{r}_{j, t+1}\right)^{2}}{\sum_{t=N}^{T}\left(r_{j, t+1}-\bar{r}_{j, t+1}\right)^{2}},
$$

where $\hat{r}_{j, t+1}$ stands for the out-of-sample forecast obtained from model (5) using only data available at $t, N$ is the break point splitting the whole sample for the out-of-sample analysis. Positive values for $R_{O O S}^{2}$ indicate that the predictor outperforms the historical mean model in terms of the MSPE. We further test whether JKTR and World Fear significantly outperform the historical mean. For individual countries, we use the Clark \& West (2007) augmented test, i.e., testing the null of $R_{O O S}^{2} \leq 0$. Under the null hypothesis, the MSPE-adjusted test statistic of Clark \& West (2007) follows a standard 
normal distribution. Defining

$$
f_{t+1}=\left(r_{t+1}-\bar{r}_{t+1}\right)^{2}-\left[\left(r_{t+1}-\hat{r}_{t+1}\right)^{2}-\left(\bar{r}_{t+1}-\hat{r}_{t+1}\right)^{2}\right]
$$

and regressing $f_{t+1}$ on a constant, i.e., $f_{t+1}=\alpha+\epsilon_{t+1}$, the MSPE-adjusted test statistic is equal to the t-statistic of the constant. ${ }^{9}$

Table 7 reports the results using a rolling window of $N=60$ observations for the initial estimation. We present the results both for JKTR and World Fear. Aggregating all countries to one joing $R_{O O S}^{2}$, the local JKTR is a very stong predictor of future aggregate market excess returns, also out-of-sample. As in Kelly \& Jiang (2014), we find that the out-of-sample $R^{2}$ is positive and statistically significant for all horizons, while it increases with the forecast horizon. In Panel B of Table 7, we report a summary of the out-of-sample predictability for the individual country excess returns. We find that for all horizons, the average out-of-sample $R^{2}$ is positive and statistically significant for more than $60 \%$ of the countries.

Turning the focus on World Fear, we obtain similar results. Panels C and D of Table 7 show that World Fear is a similarly strong out-of-sample predictor of aggregate market excess returns, as is JKTR. Overall, the results suggest that tail risk has predictive power for international market returns both in-sample and out-of-sample.

\section{E Tail Risk and the Country Cross-Section}

In this section, we examine whether tail risk is also priced in the cross-section of aggregate country excess returns. To do this, each month, we sort the countries in

\footnotetext{
${ }^{9}$ When estimating a joint panel out-of-sample $R^{2}$ for all countries, the historical mean model is not directly nested in the panel regression model. Therefore, in these cases, we use the MSE- $t$ test using $f_{t+1}=\left(r_{t+1}-\bar{r}_{t+1}\right)^{2}-\left(r_{t+1}-\hat{r}_{t+1}\right)^{2}$ and following the steps described.
} 
ascending order of their JKTR estimates and hold the portfolios for the following $1 \mathrm{up}$ to 60 month(s). We examine the performance of the strategy that simultaneously buys the indices in the top quartile of JKTR and sells the indices in the bottom quartile of JKTR. If investors are averse to tail risk, we expect that the countries' aggregate excess returns reflect a risk premium for high tail risk.

The 4 minus 1 hedge portfolio excess returns are then regressed on risk factors in order to test whether these returns merely reflect passive exposure to standard risk factors. We rely on the following 4 -factor model:

$$
r_{i, t}=\alpha_{i}+\beta_{M K T} M K T_{t}+\beta_{S M B} S M B_{t}+\beta_{H M L} H M L_{t}+\beta_{W M L} W M L_{t}+\epsilon_{i, t},
$$

where $M K T$ stands for the market excess return, and $S M B, H M L$, and $W M L$ stand for Small Minus Big, High Minus Low, and Winners Minus Losers portfolios, respectively. ${ }^{10}$ We use the global risk factors provided on Kenneth French's webpage.

We present the results in Table 8. For the 1-month horizon, presented in Panel A, we detect a clear pattern of the annualized excess returns. These are low for portfolios 1 which contain the countries with the lowest tail risk and high for portfolio 4 . The strategy that buys portfolio 4 while simultaneously shorting portfolio 1 yields an average return of $6.4 \%$, which is statistically significant at the $5 \%$ significance level. Controlling for systematic risk factors, the alphas relative to all factor models are of similar magnitude and also statistically significant at 5\%. We note though, that the returns and alphas of the sorted returns are not monotonic. The monotonicity test of Patton \& Timmermann (2010) can neither reject the null hypothesis of a monotonically increasing nor that of a

\footnotetext{
${ }^{10}$ The model nests the mean excess return (without any factors), the CAPM (using only MKT), and the Fama \& French (1993) 3-factor model (FF-3, using MKT, SMB, and HML).
} 
monotonically decreasing relation. ${ }^{11}$

Since we find that tail risk predicts market excess returns for various horizons, we also examine holding periods greater than one month. The results for these analyses can be found in Panels B-H of Table 8. The results are qualitatively similar.

The results confirm that market participants seem to be crash averse and demand risk premia for investing in countries with high tail risks. Aggregate stock markets with higher tail risk earn higher average future and risk-adjusted returns. Tail risk is thus able to predict future international aggregate market returns and explain the cross-section of country returns.

\section{F Economic Mechanism}

In this section, we investigate one economic mechanism which could drive the reported return predictability of tail risk. If asset pricing effects are channeled by uncertainty shocks, tail risk must have a direct impact on aggregate real economic outcomes. Following Kelly \& Jiang (2014), we study the effect of tail risk on the real economy. In particular, we focus on unemployment. Unemployment rates are obtained from Datastream. $^{12}$ We focus on the World Fear index and analyze its effect on unemployment, detrended by the Hodrick-Prescott filter, over horizons between one and 60 months. ${ }^{13}$

Table 9 shows the cross-correlations between World Fear in month $t$, and unemployment of the MSCI Developed and Emerging Markets countries in month $t+0$ to $t+60$. For many countries, we detect positive and significant contemporaneous and short-term

\footnotetext{
${ }^{11}$ For the 1-month horizon, the p-values for the hypothesis of a monotonically decreasing relation is 0.84 and that for the hypothesis of a monotonically increasing relation 0.99 . The figures for alternative horizons are similar. We cannot reject any of these two hypotheses.

${ }^{12}$ For India, Qatar, and Saudi Arabia, Datastream does not contain sufficient data. Hence, we leave out these countries from this analysis.

${ }^{13}$ When using the individual JKTR, we obtain qualitatively similar results.
} 
future correlations. The contemporaneous correlations, for example, are statistically significant and positive for more than half of the countries. The correlations stay significantly positive until approximately $t+3$. The positive correlation slowly disappears when the horizon reaches 12 months and turns negative for several countries in the very long term.

Economically, an increase in World Fear is followed by an immediate increase in unemployment and hence a contraction in economic activity, followed by a slow recovery. These results hold for developed and emerging economies.

\section{Additional Analyses}

\section{A U.S. Dollar vs. Local Currencies}

The analysis in the predictability Section III.D focuses on market returns expressed in U.S. dollars. However, it might be worth repeating this analysis from the perspective of a local investor. To be more specific, we rely on local returns rather than U.S. returns and explore the extent to which they can be predicted by local tail risk and World Fear.

These results are presented in Table 10. Overall, the results for local market returns are very similar to those when using U.S. dollars. For World Fear, we detect even slightly higher adjusted $R^{2}$ s.

\section{B Alternative Thresholds}

In our main analysis we define the tail of the cross-sectional distribution of a monthly pool of daily returns as the $5 \%$ quantile, which is fixed over the sample period and across countries. We now consider alternative thresholds to test whether our results are robust to the chosen threshold. This is especially relevant since the number of firms varies for 
the different countries.

Table 11 presents the return predictability regressions of aggregate market returns for the different horizons using thresholds of $3 \%, 4 \%, 6 \%$, and $7 \%$ quantile of the crosssectional distribution. For all alternative thresholds, we obtain qualitatively similar results as for the main threshold of $5 \%$. The results thus appear to robust to the choice of the tail threshold.

\section{Conclusion}

The aim of the present paper is to analyze tail risk internationally. We investigate the interaction between the tail risk of many developed and emerging countries and combine these to develop a measure of global tail risk. We show that tail risk is highly integrated across countries. Both local and global tail risk predict future aggregate market excess returns. The return predictability is economically and statistically strong, both in-sample and out-of-sample. Further, a strategy that buys equity indices with high tail risk while selling indices associated with low tail risk generates significantly positive excess returns. Our results are robust to a variety of tests. Finally, we find that global tail risk also has an impact on future unemployment. Thus, we also provide an additional indirect channel through which tail risk influences international asset prices. Overall, tail risk appears to be a major concern for investors in international markets. 


\section{References}

Allen, F., \& Gale, D. (2000). Financial contagion. Journal of Political Economy, 108(1), $1-33$.

Amihud, Y. (2002). Illiquidity and stock returns: Cross-section and time-series effects. Journal of Financial Markets, 5(1), 31-56.

Andersen, T. G., Fusari, N., Todorov, V., et al. (2018). The pricing of tail risk and the equity premium: Evidence from international option markets. Northwestern University Working Paper.

Ang, A., \& Bekaert, G. (2007). Stock return predictability: Is it there? Review of Financial Studies, 20(3), 651-707.

Beck, T., Levine, R., \& Loayza, N. (2000). Finance and the sources of growth. Journal of Financial Economics, 58(1), 261-300.

Bekaert, G., Ehrmann, M., Fratzscher, M., \& Mehl, A. (2014). The global crisis and equity market contagion. Journal of Finance, 69(6), 2597-2649.

Bollerslev, T., Marrone, J., Xu, L., \& Zhou, H. (2014). Stock return predictability and variance risk premia: Statistical inference and international evidence. Journal of Financial and Quantitative Analysis, 49(03), 633-661.

Bollerslev, T., \& Todorov, V. (2011). Tails, fears, and risk premia. Journal of Finance, $66(6), 2165-2211$.

Bollerslev, T., Todorov, V., \& Xu, L. (2015). Tail risk premia and return predictability. Journal of Financial Economics, 118(1), 113-134.

Cameron, A. C., Gelbach, J. B., \& Miller, D. L. (2011). Robust inference with multiway clustering. Journal of Business \&f Economic Statistics, 29(2), 238-249.

Campbell, J. Y., \& Thompson, S. B. (2008). Predicting excess stock returns out of sample: Can anything beat the historical average? Review of Financial Studies, 21(4), 15091531.

Carhart, M. M. (1997). On persistence in mutual fund performance. Journal of Finance, $52(1), 57-82$.

Clark, T. E., \& West, K. D. (2007). Approximately normal tests for equal predictive accuracy in nested models. Journal of Econometrics, 138(1), 291-311.

Cremers, M., Halling, M., \& Weinbaum, D. (2015). Aggregate jump and volatility risk in the cross-section of stock returns. Journal of Finance, 70(2), 577-614.

De Guevara, J. F., Maudos, J., \& Pérez, F. (2007). Integration and competition in the European financial markets. Journal of International Money and Finance, 26(1), $26-45$.

Dungey, M., \& Gajurel, D. (2015). Contagion and banking crisis; International evidence for 2007-2009. Journal of Banking \& Finance, 60, 271-283. 
Edison, H. J., Levine, R., Ricci, L., \& Sløk, T. (2002). International financial integration and economic growth. Journal of International Money and Finance, 21 (6), 749-776.

Fama, E. F., \& French, K. R. (1993). Common risk factors in the returns on stocks and bonds. Journal of Financial Economics, 33(1), 3-56.

Granger, C. W. (1969). Investigating causal relations by econometric models and crossspectral methods. Econometrica, 3(3), 424-438.

Griffin, J. M., Kelly, P. J., \& Nardari, F. (2010). Do market efficiency measures yield correct inferences? A comparison of developed and emerging markets. Review of Financial Studies, 23(8), 3225-3277.

Hamao, Y., Masulis, R. W., \& Ng, V. (1990). Correlations in price changes and volatility across international stock markets. Review of Financial Studies, 3(2), 281-307.

Hill, B. M. (1975). A simple general approach to inference about the tail of a distribution. Annals of Statistics, 3(5), 1163-1174.

Hou, K., Karolyi, G. A., \& Kho, B.-C. (2011). What factors drive global stock returns? Review of Financial Studies, 24(8), 2527-2574.

Hou, K., \& Loh, R. K. (2016). Have we solved the idiosyncratic volatility puzzle? Journal of Financial Economics, 121(1), 167-194.

Ince, O. S., \& Porter, R. B. (2006). Individual equity return data from Thomson Datastream: Handle with care! Journal of Financial Research, 29(4), 463-479.

Karolyi, G. A. (2003). Does international financial contagion really exist? International Finance, 6(2), 179-199.

Kelly, B., \& Jiang, H. (2014). Tail risk and asset prices. Review of Financial Studies, $27(10), 2841-2871$.

King, R. G., \& Levine, R. (1993). Finance, entrepreneurship and growth. Journal of Monetary Economics, 32(3), 513-542.

Lee, K.-H. (2011). The world price of liquidity risk. Journal of Financial Economics, $99(1), 136-161$.

Lesmond, D. A. (2005). Liquidity of emerging markets. Journal of Financial Economics, $77(2), 411-452$.

Levine, R. (1997). Financial development and economic growth: Views and agenda. Journal of Economic Literature, 35(2), 688-726.

Levine, R., Loayza, N., \& Beck, T. (2000). Financial intermediation and growth: Causality and causes. Journal of Monetary Economics, 46(1), 31-77.

Lin, W.-L., Engle, R. F., \& Ito, T. (1994). Do bulls and bears move across borders? International transmission of stock returns and volatility. Review of Financial Studies, $7(3), 507-538$. 
Newey, W. K., \& West, K. D. (1987). Hypothesis testing with efficient method of moments estimation. International Economic Review, 28(3), 777-787.

Patton, A. J., \& Timmermann, A. (2010). Monotonicity in asset returns: New tests with applications to the term structure, the CAPM, and portfolio sorts. Journal of Financial Economics, 98(3), 605-625.

Petersen, M. A. (2009). Estimating standard errors in finance panel data sets: Comparing approaches. Review of Financial Studies, 22(1), 435-480.

Rajan, R. G., \& Zingales, L. (1998). Financial dependence and growth. American Economic Review, 88(3), 559-586.

Sarazervos, R. L. (1998). Stock markets, banks, and economic growth. American Economic Review, 88(3), 537-558.

Wang, Y. (2016). An ignored risk factor in international markets: Tail risk. Purdue University Working Paper.

Welch, I., \& Goyal, A. (2008). A comprehensive look at the empirical performance of equity premium prediction. Review of Financial Studies, 21 (4), 1455-1508. 


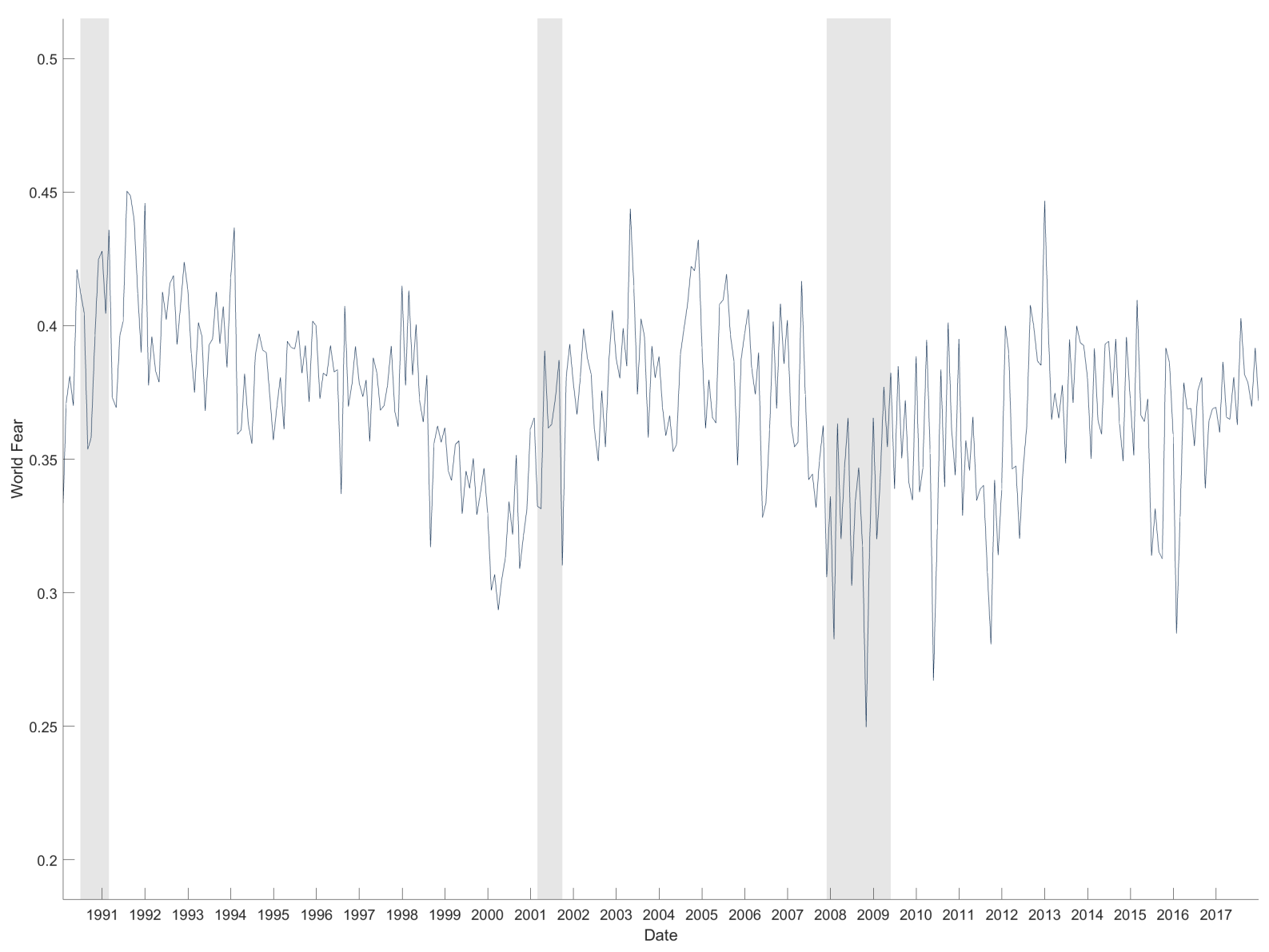

Figure 1: World Fear

This figure shows the monthly time series of World Fear for the period from January 1990 to December 2017. The shaded area indicates business cycle contractions (in the U.S.) as identified by the National Bureau of Economic Research. 


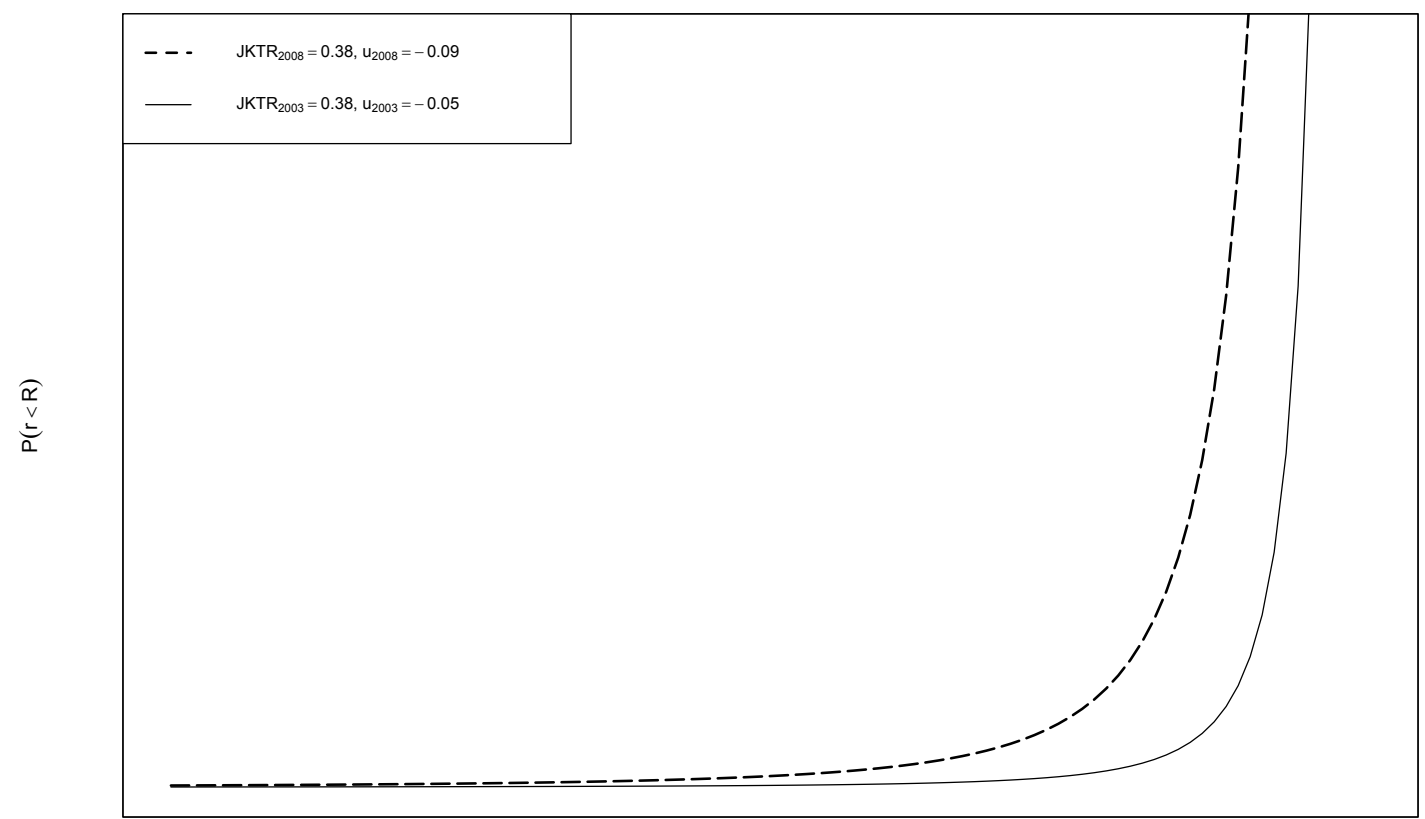

R

Figure 2: Tail of the Return Distribution

This figure shows tail probability distribution of the U.S. using decay parameter and thresholds of both a relatively calm period (in September 2003) and during the financial crisis (in September 2008). It illustrates how the impact of financial distress is diminished by allowing for a time-varying threshold $u_{t}$. 


\section{Table 1: Summary Statistics of Returns}

This table presents descriptive statistics for the daily returns (in percentage points) in U.S. dollar currency of all MSCI Developed and Emerging Markets countries for the period from January 1990 until December 2017. We report time-series averages of selected quantiles $(q(0.05), q(0.25), q(0.50), q(0.75)$, and $q(0.95))$, as well as the equally-weighted mean, the standard deviation $(S D)$, the skewness (Skew) and the kurtosis (Kurt) of the cross-sectional return distribution. That is, every day we compute the quantities and average these over time to obtain the reported values. $N$ denotes the average number of firms in the cross-section for the respective country. First Obs indicates the month in which the data for the respective country starts.

\begin{tabular}{|c|c|c|c|c|c|c|c|c|c|c|c|}
\hline & $q(0.05)$ & $q(0.25)$ & Mean & $q(0.50)$ & $q(0.75)$ & $q(0.95)$ & $S D$ & Skew & Kurt & $N$ & First Obs \\
\hline Australia & -4.62 & -0.78 & 0.04 & -0.02 & 0.75 & 4.86 & 3.08 & 0.49 & 8.61 & 464 & 1.1994 \\
\hline Austria & -2.82 & -0.42 & 0.03 & -0.00 & 0.44 & 3.02 & 1.85 & 0.18 & 8.12 & 72.3 & 1.1990 \\
\hline Belgium & -2.67 & -0.49 & 0.03 & -0.02 & 0.51 & 2.91 & 1.79 & 0.26 & 8.40 & 113 & 1.1990 \\
\hline Brazil & -3.19 & -0.48 & 0.05 & -0.04 & 0.46 & 3.57 & 2.21 & 0.39 & 9.07 & 106 & 7.1994 \\
\hline Canada & -7.49 & -1.32 & 0.09 & -0.03 & 1.14 & 8.29 & 4.94 & 0.64 & 8.19 & 1,170 & 1.1994 \\
\hline Chile & -1.42 & -0.06 & 0.04 & -0.00 & 0.07 & 1.70 & 1.00 & 0.39 & 9.73 & 66.9 & 1.1994 \\
\hline China & -3.05 & -1.28 & 0.09 & -0.16 & 1.18 & 4.12 & 2.21 & 0.75 & 5.05 & 750 & 1.1994 \\
\hline Colombia & -1.86 & -0.24 & 0.04 & -0.02 & 0.26 & 2.16 & 1.46 & 0.20 & 9.61 & 26.4 & 7.1994 \\
\hline Czech Republic & -3.05 & -0.22 & 0.05 & 0.02 & 0.25 & 3.32 & 1.89 & 0.40 & 9.68 & 98.0 & 12.1994 \\
\hline Denmark & -2.95 & -0.50 & 0.05 & -0.02 & 0.51 & 3.26 & 1.97 & 0.35 & 8.45 & 156 & 1.1994 \\
\hline Egypt & -3.26 & -0.90 & 0.04 & -0.07 & 0.84 & 3.80 & 2.13 & 0.34 & 5.63 & 62.4 & 10.1996 \\
\hline Finland & -3.42 & -0.80 & 0.05 & -0.02 & 0.84 & 3.74 & 2.23 & 0.29 & 6.73 & 97.1 & 1.1990 \\
\hline France & -3.38 & -0.55 & 0.04 & -0.01 & 0.51 & 3.77 & 2.28 & 0.45 & 8.40 & 684 & 1.1990 \\
\hline Germany & -3.88 & -0.86 & 0.02 & -0.03 & 0.75 & 4.20 & 2.48 & 0.42 & 6.86 & 532 & 1.1990 \\
\hline Greece & -3.99 & -1.20 & 0.05 & -0.06 & 1.16 & 4.61 & 2.62 & 0.35 & 5.49 & 162 & 1.1990 \\
\hline Hong Kong & -4.39 & -1.21 & 0.01 & -0.11 & 1.03 & 4.91 & 2.97 & 0.48 & 7.43 & 130 & 1.1994 \\
\hline Hungary & -3.96 & -0.72 & 0.07 & -0.04 & 0.69 & 4.56 & 3.12 & 0.25 & 10.1 & 32.1 & 4.1994 \\
\hline India & -5.06 & -1.37 & 0.06 & -0.08 & 1.28 & 5.66 & 3.15 & 0.39 & 4.93 & 284 & 1.1994 \\
\hline Indonesia & -3.76 & -0.46 & -0.04 & -0.05 & 0.34 & 3.79 & 2.48 & 0.11 & 9.20 & 25.0 & 1.1994 \\
\hline Ireland & -3.82 & -0.76 & 0.06 & -0.01 & 0.81 & 4.23 & 2.49 & 0.24 & 7.33 & 25.5 & 1.1990 \\
\hline Israel & -3.46 & -0.73 & 0.03 & -0.03 & 0.72 & 3.73 & 2.29 & 0.25 & 7.64 & 283 & 1.1994 \\
\hline Italy & -2.86 & -0.97 & 0.02 & -0.07 & 0.88 & 3.21 & 1.87 & 0.47 & 5.52 & 186 & 1.1990 \\
\hline Japan & -3.44 & -1.09 & 0.03 & -0.04 & 0.99 & 3.80 & 2.23 & 0.52 & 5.64 & 2,412 & 1.1994 \\
\hline Malaysia & -2.82 & -0.85 & 0.02 & -0.04 & 0.78 & 3.14 & 1.86 & 0.35 & 6.04 & 99.3 & 1.1994 \\
\hline Mexico & -2.53 & -0.54 & 0.04 & -0.03 & 0.54 & 2.89 & 1.70 & 0.38 & 6.62 & 28.8 & 1.1994 \\
\hline New Zealand & -2.71 & -0.50 & 0.05 & -0.01 & 0.56 & 2.97 & 1.89 & 0.23 & 7.63 & 50.3 & 1.1994 \\
\hline Netherlands & -2.87 & -0.78 & 0.04 & -0.04 & 0.76 & 3.20 & 1.91 & 0.37 & 6.97 & 119 & 1.1990 \\
\hline Norway & -3.93 & -0.84 & 0.04 & -0.04 & 0.82 & 4.31 & 2.59 & 0.39 & 7.49 & 148 & 1.1994 \\
\hline Pakistan & -3.05 & -0.62 & 0.06 & -0.04 & 0.64 & 3.57 & 1.98 & 0.18 & 6.58 & 54.7 & 1.1994 \\
\hline Peru & -1.94 & -0.08 & 0.06 & 0.00 & 0.12 & 2.27 & 1.57 & 0.33 & 12.9 & 39.7 & 1.1994 \\
\hline Philippines & -3.05 & -0.63 & 0.07 & -0.03 & 0.60 & 3.58 & 2.50 & 0.34 & 9.49 & 28.6 & 2.1994 \\
\hline Poland & -4.27 & -1.11 & 0.04 & -0.04 & 1.06 & 4.68 & 2.80 & 0.38 & 6.85 & 211 & 1.1995 \\
\hline Portugal & -2.74 & -0.36 & 0.03 & -0.01 & 0.33 & 3.01 & 2.00 & 0.35 & 9.99 & 58.5 & 1.1990 \\
\hline Qatar & -2.72 & -0.88 & 0.05 & -0.06 & 0.85 & 3.32 & 1.93 & 0.42 & 6.76 & 36.3 & 1.2005 \\
\hline Russia & -3.59 & -0.74 & 0.08 & -0.05 & 0.66 & 4.17 & 2.73 & 0.56 & 9.62 & 78.1 & 5.2002 \\
\hline Saudi Arabia & -2.71 & -1.10 & 0.05 & -0.17 & 0.92 & 3.71 & 2.03 & 0.89 & 6.29 & 118 & 2.2004 \\
\hline Singapore & -3.46 & -0.86 & 0.02 & -0.03 & 0.77 & 3.79 & 2.28 & 0.33 & 7.11 & 82.3 & 1.1994 \\
\hline South Africa & -3.04 & -0.73 & 0.05 & -0.03 & 0.77 & 3.37 & 1.98 & 0.28 & 6.67 & 143 & 1.1994 \\
\hline South Korea & -5.01 & -1.82 & 0.07 & -0.19 & 1.57 & 6.34 & 3.47 & 0.74 & 5.72 & 1,271 & 1.1994 \\
\hline Spain & -2.64 & -0.68 & 0.03 & -0.03 & 0.65 & 2.89 & 1.72 & 0.43 & 6.69 & 130 & 1.1990 \\
\hline Sweden & -4.18 & -1.19 & 0.05 & -0.06 & 1.13 & 4.68 & 2.82 & 0.47 & 6.92 & 248 & 1.1994 \\
\hline Switzerland & -2.82 & -0.64 & 0.05 & -0.02 & 0.68 & 3.10 & 1.84 & 0.33 & 6.84 & 209 & 1.1994 \\
\hline Taiwan & -3.22 & -1.27 & 0.04 & -0.13 & 1.14 & 4.04 & 2.17 & 0.55 & 4.59 & 197 & 1.1994 \\
\hline Thailand & -2.99 & -0.64 & 0.04 & -0.03 & 0.62 & 3.36 & 2.02 & 0.43 & 7.39 & 72.9 & 1.1994 \\
\hline Turkey & -3.87 & -1.50 & 0.06 & -0.22 & 1.26 & 5.15 & 2.80 & 0.86 & 6.29 & 143 & 1.1994 \\
\hline U.K. & -3.30 & -0.36 & 0.00 & -0.02 & 0.25 & 3.38 & 2.24 & 0.52 & 10.6 & 1,476 & 1.1990 \\
\hline United Arab Emirates & -2.59 & -0.30 & 0.04 & -0.00 & 0.28 & 2.97 & 1.86 & 0.22 & 10.7 & 31.2 & 1.2005 \\
\hline U.S. & -5.07 & -1.39 & 0.05 & -0.04 & 1.34 & 5.46 & 3.30 & 0.39 & 6.63 & 4,919 & 1.1990 \\
\hline
\end{tabular}




\section{Table 2: Descriptive Statistics for JKTR and World Fear}

This table presents descriptive statistics for the JKTR and World Fear for all MSCI Developed and Emerging Markets countries. Mean stands for the time-series average of the JKTR, SD stands for the standard deviation, Min and Max are the minimum and maximum values of the JKTR and $A R(1)$ indicates the first-order autocorrelation. Avg Weight is the average market capitalization weight of the respective countries. $\operatorname{Corr}_{W F}$ denotes the sample correlation of a country's JKTR with World Fear.

\begin{tabular}{|c|c|c|c|c|c|c|c|}
\hline & Mean & $S D$ & Min & $\operatorname{Max}$ & $A R(1)$ & Avg Weight & $\operatorname{Corr}_{W F}$ \\
\hline Australia & 0.425 & 0.073 & 0.247 & 0.672 & 0.632 & 0.018 & 0.534 \\
\hline Austria & 0.431 & 0.107 & 0.218 & 0.797 & 0.609 & 0.002 & 0.086 \\
\hline Belgium & 0.401 & 0.072 & 0.195 & 0.630 & 0.447 & 0.005 & 0.407 \\
\hline Brazil & 0.436 & 0.141 & 0.147 & 0.925 & 0.562 & 0.005 & 0.295 \\
\hline Canada & 0.393 & 0.062 & 0.269 & 0.573 & 0.804 & 0.025 & 0.395 \\
\hline Chile & 0.456 & 0.141 & 0.136 & 1.118 & 0.364 & 0.030 & 0.174 \\
\hline China & 0.260 & 0.093 & 0.002 & 0.532 & 0.220 & 0.032 & 0.430 \\
\hline Colombia & 0.553 & 0.245 & 0.141 & 1.655 & 0.453 & 0.001 & 0.232 \\
\hline Czech Republic & 0.407 & 0.297 & 0.011 & 1.321 & 0.621 & 0.000 & 0.279 \\
\hline Denmark & 0.401 & 0.070 & 0.196 & 0.652 & 0.540 & 0.004 & 0.430 \\
\hline Egypt & 0.293 & 0.126 & 0.017 & 0.897 & 0.537 & 0.001 & 0.262 \\
\hline Finland & 0.357 & 0.066 & 0.172 & 0.621 & 0.461 & 0.004 & 0.530 \\
\hline France & 0.413 & 0.081 & 0.183 & 0.588 & 0.737 & 0.043 & 0.241 \\
\hline Germany & 0.352 & 0.046 & 0.190 & 0.692 & 0.375 & 0.038 & 0.395 \\
\hline Greece & 0.305 & 0.099 & 0.014 & 0.625 & 0.599 & 0.002 & 0.254 \\
\hline Hong Kong & 0.359 & 0.069 & 0.212 & 0.637 & 0.640 & 0.020 & 0.395 \\
\hline Hungary & 0.534 & 0.131 & 0.236 & 0.976 & 0.390 & 0.000 & 0.267 \\
\hline India & 0.241 & 0.091 & 0.008 & 0.476 & 0.716 & 0.001 & 0.265 \\
\hline Indonesia & 0.565 & 0.205 & 0.214 & 1.146 & 0.577 & 0.001 & 0.208 \\
\hline Ireland & 0.471 & 0.128 & 0.228 & 0.963 & 0.411 & 0.002 & 0.367 \\
\hline Israel & 0.379 & 0.080 & 0.017 & 0.709 & 0.411 & 0.002 & 0.387 \\
\hline Italy & 0.290 & 0.054 & 0.119 & 0.833 & 0.359 & 0.018 & 0.459 \\
\hline Japan & 0.298 & 0.034 & 0.208 & 0.418 & 0.336 & 0.097 & 0.335 \\
\hline Malaysia & 0.336 & 0.087 & 0.198 & 0.813 & 0.473 & 0.006 & 0.158 \\
\hline Mexico & 0.376 & 0.096 & 0.132 & 0.681 & 0.246 & 0.001 & 0.291 \\
\hline New Zealand & 0.404 & 0.124 & 0.156 & 0.910 & 0.610 & 0.001 & 0.265 \\
\hline Netherlands & 0.353 & 0.066 & 0.199 & 0.547 & 0.408 & 0.016 & 0.632 \\
\hline Norway & 0.361 & 0.062 & 0.221 & 0.544 & 0.609 & 0.004 & 0.394 \\
\hline Pakistan & 0.360 & 0.236 & 0.010 & 1.369 & 0.617 & 0.001 & 0.193 \\
\hline Peru & 0.765 & 0.288 & 0.194 & 2.160 & 0.480 & 0.016 & 0.386 \\
\hline Philippines & 0.508 & 0.151 & 0.117 & 0.891 & 0.464 & 0.001 & 0.220 \\
\hline Poland & 0.355 & 0.083 & 0.042 & 0.652 & 0.582 & 0.002 & 0.369 \\
\hline Portugal & 0.501 & 0.113 & 0.226 & 0.974 & 0.452 & 0.001 & 0.350 \\
\hline Qatar & 0.370 & 0.122 & 0.076 & 0.719 & 0.586 & 0.001 & 0.035 \\
\hline Russia & 0.453 & 0.112 & 0.209 & 0.916 & 0.398 & 0.006 & 0.488 \\
\hline Saudi Arabia & 0.340 & 0.141 & 0.006 & 0.998 & 0.417 & 0.003 & 0.176 \\
\hline Singapore & 0.378 & 0.093 & 0.187 & 0.702 & 0.620 & 0.005 & 0.320 \\
\hline South Africa & 0.333 & 0.072 & 0.190 & 0.573 & 0.539 & 0.007 & 0.321 \\
\hline South Korea & 0.281 & 0.081 & 0.055 & 0.522 & 0.629 & 0.012 & 0.269 \\
\hline Spain & 0.330 & 0.062 & 0.202 & 0.900 & 0.354 & 0.015 & 0.486 \\
\hline Sweden & 0.348 & 0.063 & 0.211 & 0.570 & 0.587 & 0.009 & 0.554 \\
\hline Switzerland & 0.352 & 0.051 & 0.191 & 0.526 & 0.388 & 0.021 & 0.494 \\
\hline Taiwan & 0.257 & 0.099 & 0.014 & 0.543 & 0.483 & 0.011 & 0.352 \\
\hline Thailand & 0.390 & 0.101 & 0.154 & 0.781 & 0.428 & 0.004 & 0.065 \\
\hline Turkey & 0.285 & 0.071 & 0.106 & 0.592 & 0.354 & 0.003 & 0.191 \\
\hline U.K. & 0.463 & 0.067 & 0.291 & 0.718 & 0.556 & 0.100 & 0.742 \\
\hline United Arab Emirates & 0.694 & 0.397 & 0.120 & 4.161 & 0.402 & 0.001 & 0.099 \\
\hline U.S. & 0.357 & 0.033 & 0.236 & 0.438 & 0.528 & 0.404 & 0.754 \\
\hline World Fear & 0.371 & 0.032 & 0.250 & 0.450 & 0.553 & & 1.000 \\
\hline
\end{tabular}




\section{Table 3: Granger Causality - Bivariate}

This table summarizes the results for Granger causality tests between the JKTR of two individual countries. We test the null hypothesis that the JKTR of one individual country does not Granger-cause the JKTR of another country. The column "Granger - Causing" reports the number of countries for which the JKTR of country [name in row] Grangercauses the JKTR of others. Similarly, the column "Granger - Caused" reports the number of countries that Granger-cause the JKTR of country [name in row]. We use a significance level of $10 \%$.

\begin{tabular}{|c|c|c|}
\hline & Granger-Causing & Granger-Caused \\
\hline Australia & 12 & 30 \\
\hline Austria & 10 & 34 \\
\hline Belgium & 19 & 24 \\
\hline Brazil & 23 & 28 \\
\hline Canada & 21 & 35 \\
\hline Chile & 15 & 28 \\
\hline China & 13 & 31 \\
\hline Colombia & 20 & 35 \\
\hline Czech Republic & 22 & 33 \\
\hline Denmark & 16 & 22 \\
\hline Egypt & 16 & 36 \\
\hline Finland & 32 & 31 \\
\hline France & 32 & 35 \\
\hline Germany & 32 & 22 \\
\hline Greece & 24 & 35 \\
\hline Hong Kong & 30 & 29 \\
\hline Hungary & 18 & 27 \\
\hline India & 32 & 28 \\
\hline Indonesia & 13 & 33 \\
\hline Ireland & 21 & 27 \\
\hline Israel & 19 & 35 \\
\hline Italy & 33 & 21 \\
\hline Japan & 33 & 13 \\
\hline Malaysia & 22 & 31 \\
\hline Mexico & 27 & 22 \\
\hline New Zealand & 22 & 23 \\
\hline Netherlands & 27 & 19 \\
\hline Norway & 25 & 15 \\
\hline Pakistan & 28 & 27 \\
\hline Peru & 20 & 19 \\
\hline Philippines & 32 & 30 \\
\hline Poland & 30 & 18 \\
\hline Portugal & 29 & 20 \\
\hline Qatar & 18 & 24 \\
\hline Russia & 28 & 20 \\
\hline Saudi Arabia & 20 & 28 \\
\hline Singapore & 37 & 22 \\
\hline South Africa & 22 & 23 \\
\hline South Korea & 36 & 24 \\
\hline Spain & 34 & 11 \\
\hline Sweden & 40 & 16 \\
\hline Switzerland & 32 & 15 \\
\hline Taiwan & 34 & 20 \\
\hline Thailand & 30 & 25 \\
\hline Turkey & 29 & 25 \\
\hline U.K. & 34 & 19 \\
\hline United Arab Emirates & 16 & 36 \\
\hline U.S. & 42 & 16 \\
\hline
\end{tabular}




\section{Table 4: JTKR vs. World Fear}

This table reports results from the following regression: $J K T R_{i, t}=a_{i}+b_{i} W F_{t}+\epsilon_{i, t}$ where $J K T R_{i, t}$ is the tail risk of country $i$ at time $t, W F_{t}$ is World Fear at time $t$ and $\epsilon_{i, t}$ is the error term. Robust Newey \& West (1987) standard errors with 5 lags are reported in parentheses. Stars indicate the significance of the estimates: ${ }^{*}$ at the $10 \%$ level, ${ }^{* *}$ at the $5 \%$ level, and ${ }^{* * *}$ at the $1 \%$ level.

\begin{tabular}{|c|c|c|c|c|c|}
\hline & Constant & (s.e.) & $W F$ & (s.e.) & $R_{A d j}^{2}$ \\
\hline Australia & -0.0425 & $(0.0507)$ & $1.2758^{* * *}$ & $(0.1442)$ & 0.2827 \\
\hline Austria & $0.3239^{* * *}$ & $(0.1159)$ & 0.2886 & $(0.3165)$ & 0.0044 \\
\hline Belgium & 0.0586 & $(0.0428)$ & $0.9236^{* * *}$ & $(0.1214)$ & 0.1632 \\
\hline Brazil & -0.0669 & $(0.1487)$ & $1.3742^{* * *}$ & $(0.4018)$ & 0.0840 \\
\hline Canada & $0.0962^{*}$ & $(0.0503)$ & $0.8105^{* * *}$ & $(0.1506)$ & 0.1527 \\
\hline Chile & 0.1607 & $(0.1097)$ & $0.8063^{* * *}$ & $(0.2932)$ & 0.0269 \\
\hline China & $-0.2104^{* *}$ & $(0.1000)$ & $1.2943^{* * *}$ & $(0.2693)$ & 0.1815 \\
\hline Colombia & -0.1322 & $(0.2144)$ & $1.8732^{* * *}$ & $(0.5850)$ & 0.0498 \\
\hline Czech Republic & -0.6359 & $(0.3934)$ & $2.8231^{* *}$ & $(1.0884)$ & 0.0719 \\
\hline Denmark & 0.0408 & $(0.0480)$ & $0.9827^{* * *}$ & $(0.1349)$ & 0.1819 \\
\hline Egypt & -0.0933 & $(0.1372)$ & $1.0614^{* * *}$ & $(0.3742)$ & 0.0648 \\
\hline Finland & -0.0511 & $(0.0468)$ & $1.0999^{* * *}$ & $(0.1307)$ & 0.2788 \\
\hline France & $0.1850^{* *}$ & $(0.0879)$ & $0.6160^{* *}$ & $(0.2544)$ & 0.0554 \\
\hline Germany & $0.1394^{* * *}$ & $(0.0362)$ & $0.5725^{* * *}$ & $(0.1017)$ & 0.1534 \\
\hline Greece & 0.0111 & $(0.1021)$ & $0.7927^{* * *}$ & $(0.2634)$ & 0.0618 \\
\hline Hong Kong & 0.0309 & $(0.0589)$ & $0.8969^{* * *}$ & $(0.1718)$ & 0.1534 \\
\hline Hungary & 0.1125 & $(0.1221)$ & $1.1529^{* * *}$ & $(0.3301)$ & 0.0678 \\
\hline India & -0.0495 & $(0.1054)$ & $0.7927^{* * *}$ & $(0.2929)$ & 0.0668 \\
\hline Indonesia & -0.4107 & $(0.5752)$ & $2.5664^{*}$ & $(1.4833)$ & 0.0219 \\
\hline Ireland & -0.0756 & $(0.1171)$ & $1.4738^{* * *}$ & $(0.3148)$ & 0.1321 \\
\hline Israel & 0.0040 & $(0.0534)$ & $1.0236^{* * *}$ & $(0.1479)$ & 0.1465 \\
\hline Italy & 0.0014 & $(0.0557)$ & $0.7785^{* * *}$ & $(0.1529)$ & 0.2086 \\
\hline Japan & $0.1610^{* * *}$ & $(0.0286)$ & $0.3735^{* * *}$ & $(0.0803)$ & 0.1093 \\
\hline Malaysia & $0.1705^{* * *}$ & $(0.0625)$ & $0.4505^{* *}$ & $(0.1759)$ & 0.0217 \\
\hline Mexico & 0.0478 & $(0.0604)$ & $0.9004^{* * *}$ & $(0.1697)$ & 0.0809 \\
\hline New Zealand & 0.0095 & $(0.1163)$ & $1.0774^{* * *}$ & $(0.3224)$ & 0.0669 \\
\hline Netherlands & $-0.1332^{* * *}$ & $(0.0404)$ & $1.3108^{* * *}$ & $(0.1125)$ & 0.3974 \\
\hline Norway & 0.0679 & $(0.0519)$ & $0.8010^{* * *}$ & $(0.1488)$ & 0.1525 \\
\hline Pakistan & -0.1985 & $(0.2299)$ & $1.5172^{* *}$ & $(0.6352)$ & 0.0334 \\
\hline Peru & $-0.5974^{*}$ & $(0.3303)$ & $3.6985^{* * *}$ & $(0.8961)$ & 0.1447 \\
\hline Philippines & 0.0518 & $(0.2313)$ & $1.2393^{* *}$ & $(0.6118)$ & 0.0410 \\
\hline Poland & -0.0119 & $(0.0653)$ & $1.0024^{* * *}$ & $(0.1791)$ & 0.1328 \\
\hline Portugal & 0.0404 & $(0.0763)$ & $1.2403^{* * *}$ & $(0.2113)$ & 0.1201 \\
\hline Qatar & $0.3204^{*}$ & $(0.1927)$ & 0.1376 & $(0.5382)$ & -0.0052 \\
\hline Russia & $-0.1788^{* *}$ & $(0.0814)$ & $1.7250^{* * *}$ & $(0.2340)$ & 0.2344 \\
\hline Saudi Arabia & 0.0580 & $(0.1751)$ & 0.7740 & $(0.4732)$ & 0.0250 \\
\hline Singapore & 0.0204 & $(0.0916)$ & $0.9760^{* * *}$ & $(0.2608)$ & 0.0992 \\
\hline South Africa & 0.0554 & $(0.0661)$ & $0.7584^{* * *}$ & $(0.1835)$ & 0.1001 \\
\hline South Korea & 0.0198 & $(0.0999)$ & $0.7119^{* * *}$ & $(0.2705)$ & 0.0689 \\
\hline Spain & -0.0204 & $(0.0425)$ & $0.9454^{* * *}$ & $(0.1185)$ & 0.2337 \\
\hline Sweden & -0.0706 & $(0.0528)$ & $1.1433^{* * *}$ & $(0.1550)$ & 0.3049 \\
\hline Switzerland & 0.0511 & $(0.0440)$ & $0.8226^{* * *}$ & $(0.1195)$ & 0.2409 \\
\hline Taiwan & -0.1615 & $(0.0998)$ & $1.1432^{* * *}$ & $(0.2683)$ & 0.1208 \\
\hline Thailand & $0.3100^{* * *}$ & $(0.0872)$ & 0.2179 & $(0.2375)$ & 0.0007 \\
\hline Turkey & $0.1220^{*}$ & $(0.0634)$ & $0.4451^{* *}$ & $(0.1756)$ & 0.0329 \\
\hline U.K. & $-0.1142^{* * *}$ & $(0.0372)$ & $1.5571^{* * *}$ & $(0.1043)$ & 0.5496 \\
\hline United Arab Emirates & 0.2414 & $(0.5114)$ & 1.2503 & $(1.4564)$ & 0.0034 \\
\hline U.S. & $0.0671^{* * *}$ & $(0.0216)$ & $0.7808^{* * *}$ & $(0.0574)$ & 0.5675 \\
\hline
\end{tabular}




\section{Table 5: Return Predictability Regressions}

This table presents results for monthly return predictability regressions of market index excess returns in U.S. dollar currency over horizons from one month to five years. We run one joint panel regression using all MSCI Developed and Emerging Markets countries. The return predictor is the JKTR of the respective country. Robust two-way clustered standard errors of Cameron et al. (2011) are reported in parentheses. Stars indicate the significance of the estimates: ${ }^{*}$ at the $10 \%$ level, ${ }^{* *}$ at the $5 \%$ level, and ${ }^{* * *}$ at the $1 \%$ level.

\begin{tabular}{lcccccccc}
\hline \hline Horizon & 1 & 3 & 6 & 9 & 12 & 24 & 36 & 60 \\
\hline Constant & -0.0529 & -0.0435 & -0.0195 & -0.0175 & -0.0197 & -0.0192 & -0.0076 & 0.0140 \\
(s.e.) & $(0.0624)$ & $(0.0422)$ & $(0.0332)$ & $(0.0291)$ & $(0.0268)$ & $(0.0195)$ & $(0.0171)$ & $(0.0146)$ \\
JKTR & $0.2597^{* * *}$ & $0.2336^{* * *}$ & $0.1725^{* * *}$ & $0.1646^{* * *}$ & $0.1665^{* * *}$ & $0.1536^{* * *}$ & $0.1214^{* * *}$ & $0.0732^{* *}$ \\
(s.e.) & $(0.0959)$ & $(0.0685)$ & $(0.0551)$ & $(0.0526)$ & $(0.0515)$ & $(0.0455)$ & $(0.0449)$ & $(0.0373)$ \\
Adj. R ${ }^{2}$ & 0.0016 & 0.0034 & 0.0033 & 0.0045 & 0.0062 & 0.0115 & 0.0116 & 0.0079 \\
\hline \hline
\end{tabular}

\section{Table 6: Return Predictability - World Fear}

This table presents results for monthly return predictability regressions of market index excess returns in U.S. dollar currency over horizons from one month to five years. We run one joint panel regression using all MSCI Developed and Emerging Markets countries. The return predictor is World Fear. Robust two-way clustered standard errors of Cameron et al. (2011) are reported in parentheses. Stars indicate the significance of the estimates: ${ }^{*}$ at the $10 \%$ level, ${ }^{* *}$ at the $5 \%$ level, and ${ }^{* * *}$ at the $1 \%$ level.

\begin{tabular}{lcccccccc}
\hline \hline Horizon & 1 & 3 & 6 & 9 & 12 & 24 & 36 & 60 \\
\hline Constant & -0.7451 & $-0.6211^{* *}$ & $-0.5365^{* *}$ & $-0.5590^{* *}$ & $-0.5245^{* *}$ & $-0.3465^{* * *}$ & $-0.2698^{* * *}$ & -0.0720 \\
(s.e.) & $(0.4936)$ & $(0.3083)$ & $(0.2489)$ & $(0.2277)$ & $(0.2060)$ & $(0.1265)$ & $(0.0993)$ & $(0.0637)$ \\
WF & $2.1721^{*}$ & $1.8327^{* *}$ & $1.6047^{* *}$ & $1.6657^{* * *}$ & $1.5699^{* * *}$ & $1.0737^{* * *}$ & $0.8619^{* * *}$ & $0.3335^{*}$ \\
(s.e.) & $(1.2943)$ & $(0.8072)$ & $(0.6543)$ & $(0.6009)$ & $(0.5447)$ & $(0.3412)$ & $(0.2704)$ & $(0.1758)$ \\
Adj. R ${ }^{2}$ & 0.0053 & 0.0100 & 0.0140 & 0.0225 & 0.0268 & 0.0265 & 0.0271 & 0.0077 \\
\hline \hline
\end{tabular}




\section{Table 7: Return Predictability Regressions - Out-of-Sample $R^{2}$}

This table presents results for monthly out-of-sample return forecasts. Out-of-sample $R^{2} \mathrm{~s}$ from predictive regressions of country market index excess returns in U.S. dollar currency over horizons from one month to five years are reported. We estimate the coefficients of the predictive regression with a panel regression using all MSCI Developed and Emerging Markets countries. In Panels $\mathrm{A}$ and $\mathrm{C}$, we report the results for a joint out-of-sample predictability test using the entire panel of countries. In Panels B and D, we report aggregate statistics about the out-of-sample predictability in the individual countries. [Share Significant] denotes the fraction of countries for which the out-of-sample $R^{2}$ s are significantly positive. To obtain statistical significance, for Panels $\mathrm{A}$ and $\mathrm{C}$ we conduct a MSE- $t$ test using two-way clustered standard errors of Cameron et al. (2011). For individual countries in Panels B and D, we conduct a Clark \& West (2007) MSPE test using Newey \& West (1987) standard errors with 5 lags. The null hypothesis is that the recursive mean model outperforms the predictive model, i.e., $R_{O O S} \leq 0$. In each month $t$ (beginning at $t=60$ ), we estimate rolling univariate forecasting regressions of monthly market returns on the lagged country JKTR (Panels A and B) or World Fear index WF (Panels C and D). Stars indicate the significance of the estimates: ${ }^{*}$ at the $10 \%$ level, ${ }^{* *}$ at the $5 \%$ level, and ${ }^{* * *}$ at the $1 \%$ level.

\begin{tabular}{lcccccccc}
\hline \hline Horizon & 1 & 3 & 6 & 9 & 12 & 24 & 36 & 60 \\
\hline Panel A: Panel Out-of-Sample & $R^{2}(\mathrm{JKTR})$ & & & & & \\
\hline$R_{\text {OOS }}^{2}$ & $0.0181^{* * *}$ & $0.0411^{* * *}$ & $0.0631^{* * *}$ & $0.0935^{* * *}$ & $0.1478^{* *}$ & $0.2649^{* * *}$ & $0.4251^{* * *}$ & $0.5378^{* * *}$ \\
MSE- ) & $(2.9794)$ & $(3.1385)$ & $(2.6988)$ & $(2.6210)$ & $(2.3274)$ & $(2.4502)$ & $(2.9162)$ & $(3.3577)$ \\
\hline Panel B: Country & Out-of-Sample $R^{2}(\mathrm{JKTR})$ & & & & & \\
\hline Med. $R_{\text {OOS }}^{2}$ & 0.0161 & 0.0378 & 0.0637 & 0.0873 & 0.1163 & 0.2073 & 0.2988 & 0.3636 \\
(Med. MSPE) & $(1.6421)$ & $(1.7206)$ & $(1.7479)$ & $(1.7214)$ & $(1.7844)$ & $(2.3836)$ & $(2.6986)$ & $(4.1638)$ \\
[Share Significant] & {$[0.6875]$} & {$[0.6042]$} & {$[0.6458]$} & {$[0.6250]$} & {$[0.6458]$} & {$[0.6875]$} & {$[0.7292]$} & {$[0.7500]$} \\
\hline Panel C: Panel Out-of-Sample & $R^{2}($ World Fear $)$ & & & & & \\
\hline$R_{O O S}^{2}$ & $0.0198^{*}$ & $0.0358^{* *}$ & $0.0571^{* *}$ & $0.0876^{* *}$ & $0.1635^{* *}$ & $0.3127^{* * *}$ & $0.3288^{* *}$ & $0.6312^{* * *}$ \\
(MSE- $t$ ) & $(1.4400)$ & $(1.6497)$ & $(1.6984)$ & $(1.8077)$ & $(2.1993)$ & $(2.3889)$ & $(2.2814)$ & $(4.2304)$ \\
\hline Panel D: Country Out-of-Sample $R^{2}($ World Fear) & & & & & \\
\hline Med. $R_{O O S}^{2}$ & 0.0161 & 0.0283 & 0.0515 & 0.0639 & 0.0904 & 0.1534 & 0.1119 & 0.4839 \\
(Med. MSPE) & $(1.7151)$ & $(1.7695)$ & $(1.7178)$ & $(1.8968)$ & $(2.0468)$ & $(2.3547)$ & $(2.8289)$ & $(4.3231)$ \\
[Share Significant] & {$[0.6458]$} & {$[0.6042]$} & {$[0.5833]$} & {$[0.6458]$} & {$[0.6875]$} & {$[0.7083]$} & {$[0.6042]$} & {$[0.8333]$} \\
\hline \hline
\end{tabular}




\section{Table 8: Country Sorts}

This table presents results from country sorts based on their tail risk. Each month, we sort the countries into 4 portfolios based on their domestic JKTR estimate. We then track 1-, 3-, 6-, 9-, 12-, 24-, 36-, and 60-month value-weighted holding period returns (in the respective panels). We report the average excess returns as well as the CAPM, global Fama \& French (1993) 3-factor model (FF-3) and Carhart (1997) 4-factor model alphas. To test the significance, we use Newey \& West (1987) standard errors, with lag length equal to the forecasting horizon, but at least 5 . Stars indicate the significance of the estimates: ${ }^{*}$ at the $10 \%$ level, ${ }^{* *}$ at the $5 \%$ level, and ${ }^{* * *}$ at the $1 \%$ level.

\begin{tabular}{|c|c|c|c|c|c|}
\hline & 1 & 2 & 3 & 4 & 4 minus 1 \\
\hline \multicolumn{6}{|c|}{ Panel A: 1-Month Horizon } \\
\hline Mean return & $\begin{array}{c}0.0087 \\
(0.0370)\end{array}$ & $\begin{array}{c}0.0471 \\
(0.0343)\end{array}$ & $\begin{array}{c}0.1076^{* * *} \\
(0.0348)\end{array}$ & $\begin{array}{c}0.0723^{*} \\
(0.0369)\end{array}$ & $\begin{array}{l}0.0636^{* *} \\
(0.0262)\end{array}$ \\
\hline CAPM alpha & $\begin{array}{c}-0.0515^{* *} \\
(0.0208)\end{array}$ & $\begin{array}{l}-0.0126 \\
(0.0144)\end{array}$ & $\begin{array}{c}0.0489^{* * *} \\
(0.0161)\end{array}$ & $\begin{array}{c}0.0159 \\
(0.0203)\end{array}$ & $\begin{array}{l}0.0673^{* *} \\
(0.0273)\end{array}$ \\
\hline FF-3 alpha & $\begin{array}{c}-0.0568^{* * *} \\
(0.0203)\end{array}$ & $\begin{array}{l}-0.0117 \\
(0.0148)\end{array}$ & $\begin{array}{c}0.0432^{* * *} \\
(0.0159)\end{array}$ & $\begin{array}{c}0.0094 \\
(0.0209)\end{array}$ & $\begin{array}{l}0.0662^{* *} \\
(0.0275)\end{array}$ \\
\hline 4-factor alpha & $\begin{array}{c}-0.0580^{* * *} \\
(0.0204)\end{array}$ & $\begin{array}{l}-0.0068 \\
(0.0155)\end{array}$ & $\begin{array}{l}0.0408^{* *} \\
(0.0164)\end{array}$ & $\begin{array}{c}0.0089 \\
(0.0230)\end{array}$ & $\begin{array}{l}0.0669^{* *} \\
(0.0264)\end{array}$ \\
\hline \multicolumn{6}{|c|}{ Panel B: 3-Month Horizon } \\
\hline Mean return & $\begin{array}{c}0.0209 \\
(0.0334)\end{array}$ & $\begin{array}{c}0.0466 \\
(0.0308)\end{array}$ & $\begin{array}{c}0.0895^{* * *} \\
(0.0314)\end{array}$ & $\begin{array}{l}0.0767^{* *} \\
(0.0342)\end{array}$ & $\begin{array}{l}0.0559^{* *} \\
(0.0229)\end{array}$ \\
\hline CAPM alpha & $\begin{array}{c}-0.0358^{*} \\
(0.0190)\end{array}$ & $\begin{array}{l}-0.0106 \\
(0.0124)\end{array}$ & $\begin{array}{c}0.0290^{* * *} \\
(0.0112)\end{array}$ & $\begin{array}{c}0.0166 \\
(0.0179)\end{array}$ & $\begin{array}{l}0.0524^{* *} \\
(0.0234)\end{array}$ \\
\hline FF-3 alpha & $\begin{array}{c}-0.0381^{* *} \\
(0.0186)\end{array}$ & $\begin{array}{l}-0.0099 \\
(0.0123)\end{array}$ & $\begin{array}{l}0.0248^{* *} \\
(0.0114)\end{array}$ & $\begin{array}{c}0.0116 \\
(0.0189)\end{array}$ & $\begin{array}{l}0.0497^{* *} \\
(0.0237)\end{array}$ \\
\hline 4 -factor alpha & $\begin{array}{c}-0.0360^{*} \\
(0.0197)\end{array}$ & $\begin{array}{l}-0.0083 \\
(0.0134)\end{array}$ & $\begin{array}{l}0.0300^{* *} \\
(0.0120)\end{array}$ & $\begin{array}{c}0.0295 \\
(0.0237)\end{array}$ & $\begin{array}{l}0.0655^{* *} \\
(0.0253)\end{array}$ \\
\hline \multicolumn{6}{|c|}{ Panel C: 6-Month Horizon } \\
\hline Mean return & $\begin{array}{c}0.0185 \\
(0.0311)\end{array}$ & $\begin{array}{l}0.0556^{* *} \\
(0.0276)\end{array}$ & $\begin{array}{c}0.0883^{* * *} \\
(0.0294)\end{array}$ & $\begin{array}{l}0.0734^{* *} \\
(0.0318)\end{array}$ & $\begin{array}{l}0.0549^{* *} \\
(0.0212)\end{array}$ \\
\hline CAPM alpha & $\begin{array}{c}-0.0395^{* *} \\
(0.0175)\end{array}$ & $\begin{array}{l}-0.0008 \\
(0.0101)\end{array}$ & $\begin{array}{c}0.0268^{* * *} \\
(0.0102)\end{array}$ & $\begin{array}{c}0.0112 \\
(0.0159)\end{array}$ & $\begin{array}{l}0.0507^{* *} \\
(0.0213)\end{array}$ \\
\hline FF-3 alpha & $\begin{array}{c}-0.0355^{* *} \\
(0.0174)\end{array}$ & $\begin{array}{l}-0.0001 \\
(0.0099)\end{array}$ & $\begin{array}{l}0.0254^{* *} \\
(0.0107)\end{array}$ & $\begin{array}{c}0.0046 \\
(0.0163)\end{array}$ & $\begin{array}{c}0.0401^{*} \\
(0.0217)\end{array}$ \\
\hline 4-factor alpha & $\begin{array}{c}-0.0336^{*} \\
(0.0200)\end{array}$ & $\begin{array}{c}0.0027 \\
(0.0109)\end{array}$ & $\begin{array}{l}0.0274^{* *} \\
(0.0112)\end{array}$ & $\begin{array}{c}0.0259 \\
(0.0207)\end{array}$ & $\begin{array}{l}0.0595^{* *} \\
(0.0236)\end{array}$ \\
\hline \multicolumn{6}{|c|}{ Panel D: 9-Month Horizon } \\
\hline Mean return & $\begin{array}{c}0.0198 \\
(0.0305)\end{array}$ & $\begin{array}{l}0.0610^{* *} \\
(0.0276)\end{array}$ & $\begin{array}{c}0.0815^{* * *} \\
(0.0286)\end{array}$ & $\begin{array}{l}0.0729^{* *} \\
(0.0313)\end{array}$ & $\begin{array}{l}0.0531^{* *} \\
(0.0212)\end{array}$ \\
\hline CAPM alpha & $\begin{array}{c}-0.0385^{* *} \\
(0.0170)\end{array}$ & $\begin{array}{c}0.0022 \\
(0.0098)\end{array}$ & $\begin{array}{c}0.0189^{*} \\
(0.0104)\end{array}$ & $\begin{array}{c}0.0085 \\
(0.0154)\end{array}$ & $\begin{array}{l}0.0470^{* *} \\
(0.0209)\end{array}$ \\
\hline FF-3 alpha & $\begin{array}{c}-0.0350^{* *} \\
(0.0174)\end{array}$ & $\begin{array}{c}0.0047 \\
(0.0099)\end{array}$ & $\begin{array}{c}0.0174 \\
(0.0108)\end{array}$ & $\begin{array}{l}-0.0025 \\
(0.0148)\end{array}$ & $\begin{array}{c}0.0325 \\
(0.0215)\end{array}$ \\
\hline 4-factor alpha & $\begin{array}{l}-0.0252 \\
(0.0188)\end{array}$ & $\begin{array}{c}0.0005 \\
(0.0101)\end{array}$ & $\begin{array}{l}0.0260^{* *} \\
(0.0113)\end{array}$ & $\begin{array}{c}0.0187 \\
(0.0163)\end{array}$ & $\begin{array}{c}0.0439^{*} \\
(0.0244)\end{array}$ \\
\hline
\end{tabular}


Table 8: Country Sorts (continued)

\begin{tabular}{|c|c|c|c|c|c|}
\hline & 1 & 2 & 3 & 4 & 4 minus 1 \\
\hline \multicolumn{6}{|c|}{ Panel E: 12-Month Horizon } \\
\hline Mean return & $\begin{array}{c}0.0190 \\
(0.0287)\end{array}$ & $\begin{array}{l}0.0652^{* *} \\
(0.0274)\end{array}$ & $\begin{array}{c}0.0808^{* * *} \\
(0.0277)\end{array}$ & $\begin{array}{l}0.0715^{* *} \\
(0.0313)\end{array}$ & $\begin{array}{l}0.0525^{* *} \\
(0.0213)\end{array}$ \\
\hline CAPM alpha & $\begin{array}{c}-0.0392^{* *} \\
(0.0157)\end{array}$ & $\begin{array}{c}0.0053 \\
(0.0095)\end{array}$ & $\begin{array}{c}0.0188^{*} \\
(0.0103)\end{array}$ & $\begin{array}{c}0.0071 \\
(0.0156)\end{array}$ & $\begin{array}{l}0.0464^{* *} \\
(0.0206)\end{array}$ \\
\hline FF-3 alpha & $\begin{array}{c}-0.0366^{* *} \\
(0.0156)\end{array}$ & $\begin{array}{c}0.0092 \\
(0.0095)\end{array}$ & $\begin{array}{c}0.0172 \\
(0.0114)\end{array}$ & $\begin{array}{l}-0.0052 \\
(0.0152)\end{array}$ & $\begin{array}{c}0.0314 \\
(0.0209)\end{array}$ \\
\hline 4-factor alpha & $\begin{array}{l}-0.0218 \\
(0.0160)\end{array}$ & $\begin{array}{c}0.0049 \\
(0.0110)\end{array}$ & $\begin{array}{c}0.0248^{*} \\
(0.0127)\end{array}$ & $\begin{array}{c}0.0097 \\
(0.0165)\end{array}$ & $\begin{array}{c}0.0316 \\
(0.0243)\end{array}$ \\
\hline \multicolumn{6}{|c|}{ Panel F: 24-Month Horizon } \\
\hline Mean return & $\begin{array}{c}0.0184 \\
(0.0257)\end{array}$ & $\begin{array}{l}0.0695^{* *} \\
(0.0269)\end{array}$ & $\begin{array}{c}0.0773^{* * *} \\
(0.0270)\end{array}$ & $\begin{array}{l}0.0693^{* *} \\
(0.0324)\end{array}$ & $\begin{array}{l}0.0509^{* *} \\
(0.0249)\end{array}$ \\
\hline CAPM alpha & $\begin{array}{c}-0.0355^{* * *} \\
(0.0133)\end{array}$ & $\begin{array}{c}0.0094 \\
(0.0096)\end{array}$ & $\begin{array}{c}0.0146 \\
(0.0106)\end{array}$ & $\begin{array}{c}0.0038 \\
(0.0167)\end{array}$ & $\begin{array}{l}0.0394^{* *} \\
(0.0195)\end{array}$ \\
\hline FF-3 alpha & $\begin{array}{c}-0.0294^{* * *} \\
(0.0111)\end{array}$ & $\begin{array}{c}0.0121 \\
(0.0076)\end{array}$ & $\begin{array}{c}0.0127 \\
(0.0131)\end{array}$ & $\begin{array}{l}-0.0090 \\
(0.0187)\end{array}$ & $\begin{array}{c}0.0205 \\
(0.0210)\end{array}$ \\
\hline 4-factor alpha & $\begin{array}{c}-0.0315^{* * *} \\
(0.0115)\end{array}$ & $\begin{array}{c}0.0153^{*} \\
(0.0090)\end{array}$ & $\begin{array}{c}0.0152 \\
(0.0141)\end{array}$ & $\begin{array}{c}0.0057 \\
(0.0177)\end{array}$ & $\begin{array}{c}0.0372^{*} \\
(0.0201)\end{array}$ \\
\hline \multicolumn{6}{|c|}{ Panel G: 36-Month Horizon } \\
\hline Mean return & $\begin{array}{c}0.0235 \\
(0.0242)\end{array}$ & $\begin{array}{c}0.0731^{* * *} \\
(0.0280)\end{array}$ & $\begin{array}{c}0.0778^{* * *} \\
(0.0263)\end{array}$ & $\begin{array}{l}0.0688^{* *} \\
(0.0339)\end{array}$ & $\begin{array}{c}0.0453^{*} \\
(0.0242)\end{array}$ \\
\hline CAPM alpha & $\begin{array}{c}-0.0307^{* * *} \\
(0.0104)\end{array}$ & $\begin{array}{c}0.0079 \\
(0.0100)\end{array}$ & $\begin{array}{c}0.0155 \\
(0.0103)\end{array}$ & $\begin{array}{c}0.0041 \\
(0.0165)\end{array}$ & $\begin{array}{l}0.0348^{* *} \\
(0.0160)\end{array}$ \\
\hline FF-3 alpha & $\begin{array}{c}-0.0281^{* * *} \\
(0.0106)\end{array}$ & $\begin{array}{c}0.0069 \\
(0.0092)\end{array}$ & $\begin{array}{c}0.0088 \\
(0.0149)\end{array}$ & $\begin{array}{l}-0.0124 \\
(0.0247)\end{array}$ & $\begin{array}{c}0.0157 \\
(0.0240)\end{array}$ \\
\hline 4-factor alpha & $\begin{array}{c}-0.0273^{* *} \\
(0.0122)\end{array}$ & $\begin{array}{c}0.0101 \\
(0.0099)\end{array}$ & $\begin{array}{c}0.0126 \\
(0.0155)\end{array}$ & $\begin{array}{l}-0.0012 \\
(0.0231)\end{array}$ & $\begin{array}{c}0.0261 \\
(0.0253)\end{array}$ \\
\hline \multicolumn{6}{|c|}{ Panel H: 60-Month Horizon } \\
\hline Mean return & $\begin{array}{c}0.0339 \\
(0.0209)\end{array}$ & $\begin{array}{c}0.0756^{* * *} \\
(0.0250)\end{array}$ & $\begin{array}{c}0.0893^{* * *} \\
(0.0226)\end{array}$ & $\begin{array}{c}0.0719^{* * *} \\
(0.0243)\end{array}$ & $\begin{array}{c}0.0380^{* * *} \\
(0.0138)\end{array}$ \\
\hline CAPM alpha & $\begin{array}{c}-0.0223^{* * *} \\
(0.0074)\end{array}$ & $\begin{array}{c}0.0127 \\
(0.0096)\end{array}$ & $\begin{array}{l}0.0266^{* *} \\
(0.0113)\end{array}$ & $\begin{array}{c}0.0175 \\
(0.0149)\end{array}$ & $\begin{array}{c}0.0398^{* * *} \\
(0.0098)\end{array}$ \\
\hline FF-3 alpha & $\begin{array}{c}-0.0335^{* * *} \\
(0.0075)\end{array}$ & $\begin{array}{l}0.0123^{*} \\
(0.0064)\end{array}$ & $\begin{array}{c}0.0172 \\
(0.0162)\end{array}$ & $\begin{array}{c}0.0056 \\
(0.0233)\end{array}$ & $\begin{array}{l}0.0391^{* *} \\
(0.0176)\end{array}$ \\
\hline 4-factor alpha & $\begin{array}{c}-0.0246^{* * *} \\
(0.0094)\end{array}$ & $\begin{array}{c}0.0074 \\
(0.0066)\end{array}$ & $\begin{array}{c}0.0239 \\
(0.0163)\end{array}$ & $\begin{array}{c}0.0203 \\
(0.0224)\end{array}$ & $\begin{array}{l}0.0449^{* *} \\
(0.0199)\end{array}$ \\
\hline
\end{tabular}




\section{Table 9: Correlations - World Fear and Unemployment}

This table displays the correlation between the estimated World Fear in month $t$ and unemployment rates of different countries in month $t+i$ ( $i$ is indicated in the column header). Unemployment rates are detrended by the Hodrick-Prescott filter. Stars indicate the significance of the estimates: ${ }^{*}$ at the $10 \%$ level, ${ }^{* *}$ at the $5 \%$ level, and ${ }^{* * *}$ at the $1 \%$ level.

\begin{tabular}{|c|c|c|c|c|c|c|c|c|c|}
\hline & 0 & 1 & 3 & 6 & 9 & 12 & 24 & 36 & 60 \\
\hline Australia & 0.08 & $0.11^{* *}$ & $0.14^{* *}$ & $0.10^{*}$ & 0.03 & 0.01 & -0.01 & -0.01 & 0.02 \\
\hline Austria & $0.13^{* *}$ & $0.16^{* * *}$ & $0.16^{* * *}$ & 0.08 & $0.09^{*}$ & 0.01 & -0.07 & 0.02 & -0.09 \\
\hline Belgium & $0.15^{* * *}$ & $0.17^{* * *}$ & 0.09 & 0.06 & $0.16^{* * *}$ & 0.03 & $-0.11^{*}$ & -0.01 & -0.04 \\
\hline Brazil & -0.00 & -0.03 & -0.06 & -0.05 & $-0.22^{*}$ & $-0.35^{* * *}$ & 0.07 & 0.18 & $-0.83^{* * *}$ \\
\hline Canada & $0.17^{* * *}$ & $0.18^{* * *}$ & 0.07 & 0.05 & 0.02 & -0.01 & -0.08 & -0.00 & -0.03 \\
\hline Chile & 0.03 & 0.04 & 0.01 & 0.03 & -0.09 & -0.07 & $0.39^{* * *}$ & $-0.27^{* *}$ & -0.14 \\
\hline China & 0.10 & 0.06 & 0.08 & 0.04 & -0.10 & $-0.22^{* * *}$ & 0.07 & -0.05 & 0.14 \\
\hline Colombia & 0.02 & 0.01 & -0.00 & -0.04 & 0.03 & $-0.16^{* *}$ & 0.03 & 0.09 & 0.00 \\
\hline Czech Republic & $0.28^{* * *}$ & $0.33^{* * *}$ & $0.36^{* * *}$ & $0.21^{* * *}$ & 0.13 & 0.05 & $-0.22^{* *}$ & -0.12 & -0.12 \\
\hline Denmark & $0.11^{* *}$ & $0.16^{* * *}$ & $0.18^{* * *}$ & 0.08 & 0.03 & -0.02 & -0.02 & 0.02 & -0.09 \\
\hline Egypt & -0.08 & -0.09 & -0.07 & 0.06 & -0.02 & 0.02 & 0.03 & 0.02 & -0.07 \\
\hline Finland & 0.02 & 0.05 & $0.12^{* *}$ & $0.11^{* *}$ & 0.05 & 0.08 & -0.02 & 0.07 & 0.00 \\
\hline France & 0.07 & 0.09 & $0.10^{*}$ & 0.08 & 0.05 & 0.06 & -0.06 & -0.01 & -0.06 \\
\hline Germany & 0.04 & 0.08 & 0.07 & $0.11^{* *}$ & 0.03 & -0.02 & 0.04 & -0.03 & $-0.10^{*}$ \\
\hline Greece & $0.18^{* *}$ & $0.15^{*}$ & 0.11 & 0.04 & -0.03 & -0.13 & -0.03 & 0.14 & -0.16 \\
\hline Hong Kong & 0.06 & $0.11^{*}$ & $0.14^{* *}$ & $0.10^{*}$ & 0.07 & 0.04 & -0.02 & -0.04 & -0.05 \\
\hline Hungary & $0.17^{* *}$ & $0.19^{* *}$ & 0.11 & 0.03 & 0.13 & 0.04 & $-0.28^{* * *}$ & $0.28^{* * *}$ & -0.12 \\
\hline \multicolumn{10}{|l|}{ India } \\
\hline Indonesia & 0.05 & 0.07 & 0.06 & 0.04 & 0.03 & -0.03 & 0.00 & -0.04 & -0.09 \\
\hline Ireland & $0.21^{* * *}$ & $0.20^{* * *}$ & 0.07 & -0.02 & -0.01 & $-0.12^{*}$ & -0.01 & -0.10 & 0.02 \\
\hline Israel & $0.16^{* * *}$ & $0.16^{* * *}$ & $0.12^{* *}$ & -0.01 & -0.03 & -0.02 & -0.01 & -0.05 & -0.05 \\
\hline Italy & 0.10 & $0.18^{* *}$ & $0.18^{* *}$ & 0.02 & 0.02 & 0.02 & $-0.15^{*}$ & 0.04 & -0.04 \\
\hline Japan & $0.13^{* *}$ & $0.12^{* *}$ & 0.08 & 0.05 & -0.04 & 0.04 & -0.08 & 0.01 & 0.03 \\
\hline Malaysia & 0.00 & -0.08 & -0.00 & -0.04 & 0.14 & -0.01 & -0.04 & 0.15 & $-0.39^{* *}$ \\
\hline Mexico & $0.15^{*}$ & 0.12 & 0.11 & -0.06 & 0.05 & -0.04 & -0.05 & -0.04 & -0.13 \\
\hline New Zealand & $0.11^{* *}$ & $0.11^{* *}$ & $0.14^{* *}$ & $0.14^{* * *}$ & 0.05 & -0.02 & -0.08 & 0.03 & 0.02 \\
\hline Netherlands & 0.10 & 0.09 & $0.15^{* *}$ & $0.23^{* * *}$ & $0.15^{* *}$ & $0.20^{* *}$ & $-0.22^{* * *}$ & 0.13 & 0.02 \\
\hline Norway & -0.05 & -0.01 & 0.04 & -0.04 & 0.06 & 0.06 & -0.03 & 0.04 & $-0.19^{* * *}$ \\
\hline Pakistan & 0.03 & 0.02 & -0.00 & 0.01 & -0.01 & -0.04 & -0.03 & -0.07 & -0.03 \\
\hline Peru & 0.01 & -0.05 & -0.03 & -0.06 & 0.01 & 0.00 & 0.01 & 0.01 & -0.02 \\
\hline Philippines & -0.04 & -0.04 & 0.02 & 0.01 & -0.03 & -0.05 & -0.00 & $0.13^{* *}$ & 0.01 \\
\hline Poland & $0.27^{* * *}$ & $0.28^{* * *}$ & $0.31^{* * *}$ & $0.24^{* * *}$ & $0.19^{* *}$ & 0.10 & $-0.22^{* * *}$ & 0.02 & -0.14 \\
\hline Portugal & $0.24^{* * *}$ & $0.22^{* * *}$ & $0.12^{*}$ & 0.06 & -0.01 & -0.07 & -0.04 & 0.04 & -0.08 \\
\hline \multicolumn{10}{|l|}{ Qatar } \\
\hline Russia & 0.00 & 0.04 & -0.01 & -0.03 & 0.07 & 0.09 & 0.06 & -0.07 & -0.07 \\
\hline \multicolumn{10}{|l|}{ Saudi Arabia } \\
\hline Singapore & 0.00 & -0.00 & 0.01 & 0.06 & 0.06 & 0.01 & 0.04 & $-0.10^{*}$ & -0.02 \\
\hline South Africa & $0.15^{*}$ & $0.16^{*}$ & $0.16^{*}$ & $0.19^{* *}$ & 0.09 & $-0.26^{* * *}$ & 0.04 & 0.04 & -0.11 \\
\hline South Korea & $0.16^{* *}$ & $0.19^{* * *}$ & $0.21^{* * *}$ & 0.10 & -0.06 & -0.05 & 0.03 & -0.07 & -0.11 \\
\hline Spain & $0.12^{* *}$ & $0.10^{*}$ & 0.05 & -0.00 & -0.03 & -0.07 & 0.00 & 0.04 & -0.07 \\
\hline Sweden & $0.20^{* * *}$ & $0.12^{*}$ & $0.12^{*}$ & 0.06 & 0.11 & -0.05 & -0.10 & 0.02 & -0.10 \\
\hline Switzerland & $0.13^{* *}$ & $0.12^{* *}$ & $0.10^{*}$ & 0.05 & 0.03 & 0.03 & -0.00 & -0.00 & -0.02 \\
\hline Taiwan & $0.17^{* * *}$ & $0.15^{* * *}$ & $0.09^{*}$ & $0.10^{*}$ & 0.03 & -0.07 & $-0.10^{*}$ & -0.02 & -0.04 \\
\hline Thailand & -0.05 & -0.02 & -0.05 & -0.08 & 0.03 & 0.02 & 0.04 & 0.01 & 0.05 \\
\hline Turkey & $0.24^{* * *}$ & $0.21^{* * *}$ & 0.10 & -0.01 & -0.00 & $-0.22^{* * *}$ & 0.05 & -0.05 & $-0.29^{* * *}$ \\
\hline U.K. & 0.07 & 0.08 & $0.09^{*}$ & 0.05 & 0.05 & 0.00 & -0.03 & 0.00 & -0.01 \\
\hline United Arab Emirates & 0.07 & 0.08 & $0.09^{*}$ & 0.05 & 0.05 & 0.00 & -0.03 & 0.00 & -0.01 \\
\hline U.S. & $0.16^{* * *}$ & $0.18^{* * *}$ & $0.17^{* * *}$ & $0.11^{* *}$ & 0.06 & -0.03 & $-0.12^{* *}$ & -0.07 & -0.09 \\
\hline
\end{tabular}




\section{Table 10: Return Predictability Regressions - Local Market Returns}

This table presents results for monthly return predictability regressions of market index returns in local currencies over horizons from one month to five years. We run one joint panel regression using all MSCI Developed and Emerging Markets countries. The return predictor is World Fear. Robust two-way clustered standard errors of Cameron et al. (2011) are reported in parentheses. Stars indicate the significance of the estimates: * at the $10 \%$ level, ${ }^{* *}$ at the $5 \%$ level, and ${ }^{* * *}$ at the $1 \%$ level.

\begin{tabular}{|c|c|c|c|c|c|c|c|c|}
\hline Horizon & 1 & 3 & 6 & 9 & 12 & 24 & 36 & 60 \\
\hline \multicolumn{9}{|c|}{ Panel A: JKTR } \\
\hline $\begin{array}{l}\text { Constant } \\
\text { (s.e.) } \\
\text { JKTR } \\
\text { (s.e.) } \\
\text { Adj. R }{ }^{2}\end{array}$ & $\begin{array}{c}0.0033 \\
(0.0528) \\
0.2026^{* *} \\
(0.0829) \\
0.0013\end{array}$ & $\begin{array}{c}0.0099 \\
(0.0412) \\
0.1862^{* * *} \\
(0.0693) \\
0.0030\end{array}$ & $\begin{array}{c}0.0255 \\
(0.0362) \\
0.1465^{* *} \\
(0.0639) \\
0.0033\end{array}$ & $\begin{array}{c}0.0248 \\
(0.0343) \\
0.1481^{* *} \\
(0.0640) \\
0.0049\end{array}$ & $\begin{array}{c}0.0248 \\
(0.0331) \\
0.1463^{* *} \\
(0.0633) \\
0.0062\end{array}$ & $\begin{array}{c}0.0253 \\
(0.0289) \\
0.1357^{* *} \\
(0.0577) \\
0.0111\end{array}$ & $\begin{array}{c}0.0337 \\
(0.0268) \\
0.1122^{* *} \\
(0.0529) \\
0.0116\end{array}$ & $\begin{array}{c}0.0510^{* *} \\
(0.0250) \\
0.0636 \\
(0.0475) \\
0.0067\end{array}$ \\
\hline \multicolumn{9}{|c|}{ Panel B: WF } \\
\hline $\begin{array}{l}\text { Constant } \\
\text { (s.e.) } \\
\text { WF } \\
\text { (s.e.) } \\
\text { Adj. R } \text { R }^{2}\end{array}$ & $\begin{array}{c}-0.8653^{* *} \\
(0.3693) \\
2.6485^{* * *} \\
(0.9858) \\
0.0088\end{array}$ & $\begin{array}{c}-0.7573^{* * *} \\
(0.2619) \\
2.3540^{* * *} \\
(0.7108) \\
0.0176\end{array}$ & $\begin{array}{c}-0.6683^{* * *} \\
(0.2304) \\
2.1112^{* * *} \\
(0.6348) \\
0.0237\end{array}$ & $\begin{array}{c}-0.6922^{* * *} \\
(0.2165) \\
2.1769^{* * *} \\
(0.6018) \\
0.0340\end{array}$ & $\begin{array}{c}-0.6597^{* * *} \\
(0.2054) \\
2.0894^{* * *} \\
(0.5750) \\
0.0379\end{array}$ & $\begin{array}{c}\text { * }-0.5377^{* * *} \\
(0.1663) \\
1.7452^{* * *} \\
(0.4815) \\
0.0419\end{array}$ & $\begin{array}{c}{ }^{*}-0.4863^{* * *} \\
(0.1490) \\
1.5999^{* * *} \\
(0.4352) \\
0.0463\end{array}$ & $\begin{array}{c}-0.2368^{* *} \\
(0.1085) \\
0.9136 * * * \\
(0.3236) \\
0.0271\end{array}$ \\
\hline
\end{tabular}




\section{Table 11: Return Predictability Regressions - Alternative Thresholds}

In this table, we run robustness tests using alternative tail risk thresholds of $3 \%, 4 \%, 6 \%$, and $7 \%$. We present results for monthly return predictability regressions of market index excess returns in U.S. dollar currency over horizons from one month to five years. We run one joint panel regression using all MSCI Developed and Emerging Markets countries. The return predictor in the different Panels is either JKTR or World Fear (WF). Robust two-way clustered standard errors of Cameron et al. (2011) are reported in parentheses. Stars indicate the significance of the estimates: ${ }^{*}$ at the $10 \%$ level, ${ }^{* *}$ at the $5 \%$ level, and *** at the $1 \%$ level.

\begin{tabular}{|c|c|c|c|c|c|c|c|c|}
\hline Horizon & 1 & 3 & 6 & 9 & 12 & 24 & 36 & 60 \\
\hline \multicolumn{9}{|c|}{ Panel A: Threshold 3\% (JKTR) } \\
\hline $\begin{array}{l}\text { Constant } \\
\text { (s.e.) }\end{array}$ & $\begin{array}{l}-0.0680 \\
(0.0607)\end{array}$ & $\begin{array}{c}-0.0497 \\
(0.0399)\end{array}$ & $\begin{array}{l}-0.0224 \\
(0.0306)\end{array}$ & $\begin{array}{l}-0.0216 \\
(0.0274)\end{array}$ & $\begin{array}{l}-0.0225 \\
(0.0255)\end{array}$ & $\begin{array}{l}-0.0182 \\
(0.0185)\end{array}$ & $\begin{array}{l}-0.0064 \\
(0.0169)\end{array}$ & $\begin{array}{c}0.0176 \\
(0.0154)\end{array}$ \\
\hline JKTR & $0.3608^{* * *}$ & $0.3019^{* * *}$ & $0.2178^{* * *}$ & $0.2121^{* * *}$ & $0.2107^{* * *}$ & $0.1835^{* * *}$ & $0.1436^{* * *}$ & 0.0778 \\
\hline (s.e.) & $(0.1139)$ & $(0.0779)$ & $(0.0595)$ & $(0.0591)$ & $(0.0579)$ & $(0.0518)$ & $(0.0531)$ & $(0.0483)$ \\
\hline Adj. $R^{2}$ & 0.0023 & 0.0042 & 0.0039 & 0.0054 & 0.0071 & 0.0117 & 0.0116 & 0.0061 \\
\hline \multicolumn{9}{|c|}{ Panel B: Threshold 3\% (WF) } \\
\hline $\begin{array}{l}\text { Constant } \\
\text { (s.e.) }\end{array}$ & $\begin{array}{l}-0.6957 \\
(0.4586)\end{array}$ & $\begin{array}{c}-0.7017^{* *} \\
(0.2914)\end{array}$ & $\begin{array}{c}-0.5251^{* *} \\
(0.2327)\end{array}$ & $\begin{array}{c}-0.5707^{* * *} \\
(0.2163)\end{array}$ & $\begin{array}{c}-0.5142^{* * *} \\
(0.1980)\end{array}$ & $\begin{array}{c}-0.3348^{* * *} \\
(0.1262)\end{array}$ & $\begin{array}{c}-0.2329^{* *} \\
(0.0964)\end{array}$ & $\begin{array}{l}-0.0516 \\
(0.0622)\end{array}$ \\
\hline WF & $2.5435^{*}$ & $2.5623^{* * *}$ & $1.9651^{* *}$ & $2.1204^{* * *}$ & $1.9264^{* * *}$ & $1.3024^{* * *}$ & $0.9527^{* * *}$ & 0.3481 \\
\hline (s.e.) & $(1.4982)$ & $(0.9509)$ & $(0.7626)$ & $(0.7122)$ & $(0.6545)$ & $(0.4251)$ & $(0.3279)$ & $(0.2155)$ \\
\hline Adj. $R^{2}$ & 0.0048 & 0.0129 & 0.0137 & 0.0238 & 0.0262 & 0.0255 & 0.0219 & 0.0054 \\
\hline \multicolumn{9}{|c|}{ Panel C: Threshold 4\% (JKTR) } \\
\hline $\begin{array}{l}\text { Constant } \\
\text { (s.e.) }\end{array}$ & $\begin{array}{l}-0.0647 \\
(0.0645)\end{array}$ & $\begin{array}{l}-0.0541 \\
(0.0420)\end{array}$ & $\begin{array}{l}-0.0271 \\
(0.0328)\end{array}$ & $\begin{array}{l}-0.0234 \\
(0.0291)\end{array}$ & $\begin{array}{c}-0.0259 \\
(0.0270)\end{array}$ & $\begin{array}{l}-0.0248 \\
(0.0194)\end{array}$ & $\begin{array}{l}-0.0125 \\
(0.0178)\end{array}$ & $\begin{array}{c}0.0122 \\
(0.0159)\end{array}$ \\
\hline JKTR & $0.3158^{* * *}$ & $0.2841^{* * *}$ & $0.2090^{* * *}$ & $0.1958^{* * *}$ & $0.1989^{* * *}$ & $0.1833^{* * *}$ & $0.1459^{* * *}$ & $0.0850^{*}$ \\
\hline (s.e.) & $(0.1127)$ & $(0.0751)$ & $(0.0595)$ & $(0.0573)$ & $(0.0559)$ & $(0.0491)$ & $(0.0508)$ & $(0.0448)$ \\
\hline Adj. $R^{2}$ & 0.0019 & 0.0041 & 0.0039 & 0.0050 & 0.0069 & 0.0128 & 0.0130 & 0.0081 \\
\hline \multicolumn{9}{|c|}{ Panel D: Threshold 4\% (WF) } \\
\hline $\begin{array}{l}\text { Constant } \\
\text { (s.e.) }\end{array}$ & $\begin{array}{l}-0.7421 \\
(0.4831)\end{array}$ & $\begin{array}{c}-0.6598^{* *} \\
(0.2969)\end{array}$ & $\begin{array}{c}-0.5530^{* *} \\
(0.2397)\end{array}$ & $\begin{array}{l}-0.5734^{* *} \\
(0.2233)\end{array}$ & $\begin{array}{l}-0.5407^{* * *} \\
(0.2041)\end{array}$ & $\begin{array}{c}{ }^{*}-0.3372^{* * *} \\
(0.1262)\end{array}$ & $\begin{array}{l}-0.2552^{* * *} \\
(0.0978)\end{array}$ & $\begin{array}{l}-0.0691 \\
(0.0628)\end{array}$ \\
\hline WF & $2.3766^{*}$ & $2.1286^{* *}$ & $1.8121^{* * *}$ & $1.8731^{* * *}$ & $1.7732^{* * *}$ & $1.1519^{* * *}$ & $0.9039^{* * *}$ & $0.3582^{*}$ \\
\hline & $(1.3897)$ & $(0.8533)$ & $(0.6917)$ & $(0.6471)$ & $(0.5928)$ & $(0.3742)$ & $(0.2927)$ & $(0.1906)$ \\
\hline Adj. $R^{2}$ & 0.0054 & 0.0114 & 0.0150 & 0.0239 & 0.0286 & 0.0256 & 0.0251 & 0.0074 \\
\hline
\end{tabular}


Table 11: Return Predictability Regressions - Alternative Thresholds (continued)

\begin{tabular}{|c|c|c|c|c|c|c|c|c|}
\hline Horizon & 1 & 3 & 6 & 9 & 12 & 24 & 36 & 60 \\
\hline \multicolumn{9}{|c|}{ Panel E: Threshold 6\% (JKTR) } \\
\hline $\begin{array}{l}\text { Constant } \\
\text { (s.e.) } \\
\text { JKTR } \\
\text { (s.e.) } \\
\text { Adj. R }{ }^{2}\end{array}$ & $\begin{array}{c}-0.0370 \\
(0.0610) \\
0.2034^{* *} \\
(0.0870) \\
0.0012\end{array}$ & $\begin{array}{c}-0.0344 \\
(0.0414) \\
0.1953^{* * *} \\
(0.0614) \\
0.0030\end{array}$ & $\begin{array}{c}-0.0144 \\
(0.0324) \\
0.1481^{* * *} \\
(0.0490) \\
0.0031\end{array}$ & $\begin{array}{c}-0.0083 \\
(0.0282) \\
0.1309^{* * *} \\
(0.0462) \\
0.0036\end{array}$ & $\begin{array}{c}-0.0103 \\
(0.0258) \\
0.1323^{* * *} \\
(0.0448) \\
0.0050\end{array}$ & $\begin{array}{c}-0.0093 \\
(0.0186) \\
0.1191^{* * *} \\
(0.0393) \\
0.0089\end{array}$ & $\begin{array}{c}0.0005 \\
(0.0158) \\
0.0933^{* *} \\
(0.0374) \\
0.0089\end{array}$ & $\begin{array}{c}0.0197 \\
(0.0136) \\
0.0543^{*} \\
(0.0315) \\
0.0056\end{array}$ \\
\hline \multicolumn{9}{|c|}{ Panel F: Threshold 6\% (WF) } \\
\hline $\begin{array}{l}\text { Constant } \\
\text { (s.e.) } \\
\text { WF } \\
\text { (s.e.) } \\
\text { Adj. } \mathrm{R}^{2}\end{array}$ & $\begin{array}{c}-0.6611 \\
(0.4976) \\
1.7996 \\
(1.2093) \\
0.0043\end{array}$ & $\begin{array}{c}-0.6319^{* *} \\
(0.3192) \\
1.7241^{* *} \\
(0.7729) \\
0.0104\end{array}$ & $\begin{array}{c}-0.5556^{* *} \\
(0.2527) \\
1.5338^{* *} \\
(0.6150) \\
0.0151\end{array}$ & $\begin{array}{c}-0.5637^{* *} \\
(0.2264) \\
1.5540^{* * *} \\
(0.5528) \\
0.0231\end{array}$ & $\begin{array}{c}-0.5273^{* * *} \\
(0.2029) \\
1.4605^{* * *} \\
(0.4958) \\
0.0273\end{array}$ & $\begin{array}{c}-0.3395^{* * *} \\
(0.1238) \\
0.9761^{* * *} \\
(0.3091) \\
0.0259\end{array}$ & $\begin{array}{c}-0.2741^{* * *} \\
(0.0976) \\
0.8084^{* * *} \\
(0.2459) \\
0.0281\end{array}$ & $\begin{array}{c}-0.0649 \\
(0.0638) \\
0.2905^{*} \\
(0.1627) \\
0.0069\end{array}$ \\
\hline \multicolumn{9}{|c|}{ Panel G: Threshold $7 \%$ (JKTR) } \\
\hline $\begin{array}{l}\text { Constant } \\
\text { (s.e.) } \\
\text { JKTR } \\
\text { (s.e.) } \\
\text { Adj. R }{ }^{2}\end{array}$ & $\begin{array}{c}-0.0225 \\
(0.0568) \\
0.1581^{* *} \\
(0.0710) \\
0.0010\end{array}$ & $\begin{array}{c}-0.0160 \\
(0.0401) \\
0.1420^{* *} \\
(0.0561) \\
0.0022\end{array}$ & $\begin{array}{c}-0.0049 \\
(0.0309) \\
0.1175^{* * *} \\
(0.0431) \\
0.0027\end{array}$ & $\begin{array}{c}-0.0004 \\
(0.0266) \\
0.1049^{* * *} \\
(0.0399) \\
0.0031\end{array}$ & $\begin{array}{c}-0.0039 \\
(0.0244) \\
0.1095^{* * *} \\
(0.0387) \\
0.0046\end{array}$ & $\begin{array}{c}-0.0022 \\
(0.0176) \\
0.0957^{* * *} \\
(0.0336) \\
0.0079\end{array}$ & $\begin{array}{c}0.0067 \\
(0.0139) \\
0.0735^{* *} \\
(0.0292) \\
0.0077\end{array}$ & $\begin{array}{c}0.0240^{*} \\
(0.0123) \\
0.0410 \\
(0.0253) \\
0.0042\end{array}$ \\
\hline \multicolumn{9}{|c|}{ Panel H: Threshold $7 \%$ (WF) } \\
\hline $\begin{array}{l}\text { Constant } \\
\text { (s.e.) } \\
\text { WF } \\
\text { (s.e.) } \\
\text { Adj. } \mathrm{R}^{2}\end{array}$ & $\begin{array}{c}-0.6653 \\
(0.4973) \\
1.6947 \\
(1.1319) \\
0.0043\end{array}$ & $\begin{array}{c}-0.6063^{*} \\
(0.3284) \\
1.5536^{* *} \\
(0.7454) \\
0.0097\end{array}$ & $\begin{array}{c}-0.5523^{* *} \\
(0.2565) \\
1.4280^{* *} \\
(0.5850) \\
0.0149\end{array}$ & $\begin{array}{c}-0.5784^{* *} \\
(0.2264) \\
1.4893^{* * *} \\
(0.5177) \\
0.0243\end{array}$ & $\begin{array}{c}-0.5361^{* * *} \\
(0.2025) \\
1.3875^{* * *} \\
(0.4633) \\
0.0282\end{array}$ & $\begin{array}{c}-0.3264^{* * *} \\
(0.1225) \\
0.8822^{* * *} \\
(0.2867) \\
0.0242\end{array}$ & $\begin{array}{c}-0.2849^{* * *} \\
(0.0967) \\
0.7814^{* * *} \\
(0.2276) \\
0.0298\end{array}$ & $\begin{array}{c}-0.0605 \\
(0.0652) \\
0.2610^{*} \\
(0.1555) \\
0.0063\end{array}$ \\
\hline
\end{tabular}

